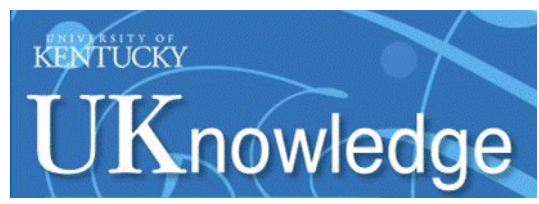

University of Kentucky

UKnowledge

\title{
$1-2017$
}

\section{Developmental Toxicity of Nicotine: A Transdisciplinary Synthesis and Implications for Emerging Tobacco Products}

Lucinda J. Enland

Centers for Disease Control and Prevention

Kjersti Aagaard

Baylor College of Medicine

Michele Bloch

National Cancer Institute

Kevin Conway

National Institute on Drug Abuse

See next page for additional authors

Right click to open a feedback form in a new tab to let us know how this document benefits you. Follow this and additional works at: https://uknowledge.uky.edu/ps_facpub

Part of the Behavior and Behavior Mechanisms Commons, Neuroscience and Neurobiology

Commons, Pharmacy and Pharmaceutical Sciences Commons, and the Substance Abuse and Addiction Commons 


\section{Developmental Toxicity of Nicotine: A Transdisciplinary Synthesis and Implications for Emerging Tobacco Products}

\section{Digital Object Identifier (DOI)}

https://doi.org/10.1016/j.neubiorev.2016.11.013

\section{Notes/Citation Information}

Published in Neuroscience \& Biobehavioral Reviews, v. 72, p. 176-189.

This manuscript version is made available under the CC-BY-NC-ND 4.0 license https://creativecommons.org/licenses/by-nc-nd/4.0/.

The document available for download is the author's post-peer-review final draft of the article.

\section{Authors}

Lucinda J. Enland, Kjersti Aagaard, Michele Bloch, Kevin Conway, Kelly Cosgrove, Rachel Grana, Thomas J. Gould, Dorothy Hatsukami, Frances Jensen, Denise Kandel, Bruce Lanphear, Frances Leslie, James R. Pauly, Jenae Neiderhiser, Mark Rubinstein, Theodore A. Slotkin, Eliot Spindel, Laura Stroud, and Lauren Wakschlag 
*Address correspondence to: Lucinda J. England, MD, CDC, 4770 Buford Highway NE, MS F-79, Atlanta GA 30341. 1be9@cdc.gov. Phone: 770-488-6266.

All authors participated in an expert meeting, Developmental Effects of Nicotine and Implications for Emerging Tobacco Products, sponsored by the Centers for Disease Control and Prevention and the National Cancer Institute, National Institutes of Health. They are listed alphabetically.

Financial disclosure

This research did not receive any specific grant from funding agencies in the public, commercial, or private sectors. The meeting "Developmental Effects of Nicotine and Implications for Emerging Tobacco Products" was held May 5-6, 2015 and was convened by the National Institutes of Health (NIH) and the Centers for Disease Control and Prevention (CDC).

The findings and conclusions of this report are those of the authors and do not necessarily represent the official position of the Centers for Disease Control and Prevention.

Publisher's Disclaimer: This is a PDF file of an unedited manuscript that has been accepted for publication. As a service to our customers we are providing this early version of the manuscript. The manuscript will undergo copyediting, typesetting, and review of the resulting proof before it is published in its final citable form. Please note that during the production process errors may be discovered which could affect the content, and all legal disclaimers that apply to the journal pertain. 
${ }^{12}$ College of Pharmacy, University of Kentucky, Lexington, KY, USA

${ }^{13}$ Department of Psychology, Pennsylvania State University, University Park, PA, USA

${ }^{14}$ Department of Pediatrics, School of Medicine, University of California, San Francisco, San

Francisco, CA, USA

${ }^{15}$ Department of Pharmacology and Cancer Biology, Duke University Medical Center, Durham, NC, USA

${ }^{16}$ Division of Neuroscience, Oregon National Primate Research Center, Oregon Health and Science University, Beaverton, OR, USA

17Department of Psychiatry and Human Behavior, Alpert Medical School, Brown University, Providence, RI. USA

${ }^{18}$ Department of Medical Social Sciences Feinberg School of Medicine, Northwestern University, Chicago, IL, USA

\section{Abstract}

While the health risks associated with adult cigarette smoking have been well described, effects of nicotine exposure during periods of developmental vulnerability are often overlooked. Using MEDLINE and PubMed literature searches, books, reports and expert opinion, a transdisciplinary group of scientists reviewed human and animal research on the health effects of exposure to nicotine during pregnancy and adolescence. A synthesis of this research supports that nicotine contributes critically to adverse effects of gestational tobacco exposure, including reduced pulmonary function, auditory processing defects, impaired infant cardiorespiratory function, and may contribute to cognitive and behavioral deficits in later life. Nicotine exposure during adolescence is associated with deficits in working memory, attention, and auditory processing, as well as increased impulsivity and anxiety. Finally, recent animal studies suggest that nicotine has a priming effect that increases addiction liability for other drugs. The evidence that nicotine adversely affects fetal and adolescent development is sufficient to warrant public health measures to protect pregnant women, children, and adolescents from nicotine exposure.

\section{Keywords}

nicotine; electronic nicotine delivery systems; priority/special populations

\section{Background}

After decades of declining cigarette sales, cigarette companies expanded their product lines to include a range of nicotine-containing products with varying levels of toxicity, including smokeless tobacco in the 1990s, and electronic cigarettes and other types of electronic nicotine delivery systems (ENDS) in the early 2000s. Some tobacco companies have also added nicotine replacement therapy (NRT) pharmaceuticals.(1-3) Electronic cigarettesdevices which create an aerosol for inhalation by heating a liquid solution that typically contains propylene glycol and/or glycerin, flavorings, and nicotine-have experienced rapid growth since their introduction into the US market.(4-6) However, their arrival has also 
engendered debate in the public health community. $(7,8)$ Those concerned about the risks from electronic cigarettes to individual and population level health note that electronic cigarettes could perpetuate conventional cigarette use in smokers who use both products instead of quitting cigarettes completely, and that adolescent users of these products could progress to conventional cigarette use. $(4,9,10)$ In contrast, others contend that electronic cigarettes have lower toxicity than conventional cigarettes, higher consumer appeal than NRT, and that their use may lead to cessation or to a reduction in toxicant exposure, thereby reducing the burden of tobacco-related death and disease.(11)

A key assertion advanced by those in favor of wide access to electronic cigarettes is that nicotine exposure presents a minimal health risk for most adult tobacco users.(12) This is based, in part, on longitudinal studies of adults exposed to nicotine from smokeless tobacco or NRT, which found lowered risk for myocardial infarction, stroke, and lung cancer compared with risk in cigarette smokers.(13-16) However, this assertion has important limitations. Electronic cigarette use is not limited to adults or to conventional cigarette smokers.(17) Use has increased dramatically in high school and middle school students since 2011, (5) and in 2014, twice as many youth used electronic cigarettes alone as in combination with cigarettes.(18) Furthermore, as will be presented here, conclusions about the risks of nicotine exposure based on studies in adults cannot be extrapolated to adolescents or pregnant women and their fetuses, because these populations have health risks unique to their particular stages of development. Nevertheless, discussions of the potential adverse health effects of nicotine among pregnant women and adolescents are often absent from discussions related to the public health impact of electronic cigarettes.

In May of 2015, scientists from varied disciplines were convened by the National Institutes of Health (NIH) and the Centers for Disease Control and Prevention (CDC) to review the scientific literature on the health effects of nicotine exposure during periods of developmental vulnerability. In this expert review, meeting participants used MEDLINE and PubMed literature searches, books, reports, and expert opinion to summarize and synthesize relevant epidemiological, clinical, and preclinical research on the health effects of exposure to tobacco and nicotine pregnancy and adolescence. Electronic cigarettes were introduced to markets relatively recently, and their effects on health outcomes in pregnant women and adolescents have not been directly assessed. In addition, there are no published studies of developmental outcomes using animal models nicotine exposure from electronic cigarettes. Therefore, the authors draw on studies of other forms of tobacco exposure (cigarettes and smokeless tobacco) in humans and conventional nicotine exposure in animals. While there is evidence from animal models that gestational nicotine exposure also affects several organ systems, including renal, hematopoietic, adipose and endocrine,(19-23) we focused on the central nervous and pulmonary systems, which are the most established and clearest targets of nicotine. In addition, shorter-term studies of exposures to electronic cigarette-derived aerosols in adult mouse models demonstrate that electronic cigarettes can produce pulmonary and behavioral effects similar to those seen with conventional nicotine exposures. (24-27) 
The implications of the increasing use of nicotine-containing products, specifically electronic cigarettes, for pregnant women and adolescents are discussed, and potential strategies for minimizing exposure in these populations are presented.

\section{Tobacco use and nicotine exposure during pregnancy}

\subsection{Pregnancy outcomes}

Maternal cigarette smoking during pregnancy is causally associated with a number of adverse pregnancy outcomes, including ectopic pregnancy, fetal growth restriction, preterm birth, placental abruption, and orofacial cleft defects.(15) Despite high awareness that smoking increases the risk of pregnancy complications,(28) over $10 \%$ of U.S. women smoke cigarettes during pregnancy, exposing more than 400,000 fetuses each year.(29) Tobacco smoke contains thousands of chemicals, many of which could contribute to adverse outcomes.(30) However, studies of pregnant women who are exposed to nicotine without products of combustion through the use of smokeless tobacco products can provide insight into the potential role of nicotine. These studies have found associations with preterm birth, stillbirth, and orofacial cleft defects, $(15,31-35)$ but no clear association with fetal growth restriction.(36-39) In agreement with the latter finding, animal models utilizing nicotine alone do not demonstrate any consistent effect on fetal growth at exposures modeling those in typical smokers.(40-42) Together, these findings provide evidence that nicotine and other tobacco smoke components produce distinctive adverse pregnancy outcomes.

\subsection{Fetal brain development}

During development, neurotransmitters control and coordinate the cellular and architectural assembly of the central nervous system. $(43,44)$ At the appropriate developmental phase, stimulation of neurotransmitter receptors regulates brain assembly by (1) promoting cell replication; (2) initiating differentiation; (3) initiating and then terminating axonogenesis and synaptogenesis; (4) regulating cell death; and (5) promoting cell migration to specific brain regions.

Acetylcholine plays a critical role in brain maturation via activation of nicotinic acetylcholine receptors (nAChRs). These receptors are a structurally diverse family of ligand-gated ion channels which regulate synaptic plasticity and brain development.

Nicotine crosses the placenta(45) and specifically binds to nAChRs in the fetal brain. $(46,47)$ Since nAChRs are functional at early stages of brain development, their early activation and/or desensitization by nicotine can lead to long-term developmental disruption.(48-50) Even first-trimester exposure can induce disruption of brain development at both cellular and structural levels.(51) Although the structural features may appear grossly normal by early adulthood,(52) a detailed analysis of synaptic architecture shows long-lasting alterations (layer thinning, loss of neuropil, glial "scarring"), particularly in the hippocampus and somatosensory cortex areas that are critical for attention and cognitive function.(52-54) Thus, from a morphological standpoint, nicotine is a subtle neuroteratogen. However, its functional consequences exceed the visible evidence of disrupted development. 
In developing rats exposed prenatally to nicotine at plasma levels comparable to those in human active smokers, standard biomarkers of cell injury indicate apoptosis, reductions in the numbers of neuronal cells, truncation of axonogenesis, and deficient synaptogenesis. (55-58) Neuronal damage and cell loss involving the activation of genes associated with apoptosis intensify in the postnatal period despite the discontinuation of nicotine exposure. $(57,59,60)$ The developmental context is critical for evoking damage, since nicotineinduced apoptosis in the immature brain is distinct from its effect in the mature brain.(61, 62) For example, hippocampal progenitor cells show nicotine-induced apoptosis only during early differentiation.(63) Furthermore, the delayed-onset changes that occur when nicotine is no longer present in the system indicate that nicotine changes the entire trajectory of brain development so that adverse effects can emerge later in life, after a period of apparent normality. This is particularly important for patterns of synaptic activity that display initial deficits in the early postnatal period, but tend to recover by juvenile stages, only to show a reemergence of hypoactivity in adolescence, $(59,64-66)$ at which point there is a persistent deficit in nAChR function.(67-70)

To characterize the involvement of nAChRs in regulating brain development during the third trimester human fetal period, studies examined the effects of nicotine exposure during the functionally-equivalent early postnatal period in rats and found altered thalamocortical maturation, resulting in subsequent impairment of cognitive behaviors. $(67,71,72)$ The hippocampus and cerebellum, which are both late maturing structures, also exhibited unique regulation by nAChRs,(73-76) and consequently, postnatal nicotine exposure disrupted morphological assembly of these regions. $(77,78)$ Thus, animal studies indicate that nicotine exposure can negatively impact all stages of fetal brain development. Indeed, it is estimated that nicotine is responsible for as much as $36 \%-46 \%$ of the overall impact of tobacco smoke on the development of brain circuitry in animal models.(79)

It is important to note that the adverse effects of nicotine on brain development occur at exposure levels that do not compromise somatic growth.(64) Maternal cigarette smoking is strongly associated with intrauterine growth retardation, a well-recognized predictor of poor perinatal outcomes.(15) However, because nicotine targets the fetal brain, damage can be present, even when birth weight is normal. This reflects the specific actions of nicotine on nAChRs that modulate neuronal development, in contrast to non-specific fetal insults, which typically spare brain development at the expense of fetal somatic growth. $(64,80,81)$

The effects of isolated nicotine exposure on human fetal brain development have not been studied directly. However, maternal cigarette smoking has measurable effects on brain structure that are consistent with animal models that evaluated nicotine alone. Imaging studies found that fetuses exposed to maternal smoking had decreased transcerebellar and lateral ventricle diameter/width (ultrasound) and decreased overall brain volume (MRI) compared with unexposed fetuses, as well as smaller frontal lobe and cerebellar volumes in infancy.(82-84) Imaging studies of offspring in later life also found differences in the brains of exposed offspring, including reduced cerebral cortical gray matter, reduced subcortical gray matter volumes in the amygdala, thalamus, and pallidum, and reduced volume in the corpus callosum.(85-90) In a study of 6- to 8-year-old children prenatally exposed to maternal smoking, the authors found reduced brain volume, smaller cortical gray and white 
matter volumes, and thinning of the superior frontal, superior parietal, lateral occipital, and precentral cortices compared with age- and gender-matched unexposed children.(91) Taken together, studies of tobacco exposure in human fetuses are in agreement with those of nicotine exposure in animals, and in particular, those which documented disruption of brain development independent of effects on fetal growth. $(83,89,91)$ The structural alterations seen in human studies are paralleled by functional changes in the fetus. Studies using realtime fetal monitoring(92-95) found greater rates of maladaptive response to the non-stress test (a clinical index of fetal well-being)(96), including reduced heart rate variability, increased mouth and self-touch movements, and impaired recognition of maternal voice in fetuses of smokers compared with those of nonsmokers.(97-99)

\subsection{Perinatal mortality and sudden infant death syndrome}

Maternal smoking during pregnancy increases the risk of perinatal mortality (which includes both stillbirth and neonatal death) by 20-30\%,(100) and of sudden infant death syndrome (SIDS) 2.4 to 3-fold.(101) Maternal smokeless tobacco use in pregnancy is associated with a 1.6 to 2.6 -fold increase in stillbirth. $(31,33)$

Maternal smoking is thought to increase perinatal mortality and SIDS risk in part through its effects on fetal and infant stress responses. Human parturition is associated with an extended period of hypoxia, and the fetus and newborn possess unique adaptive responses that maintain cardiovascular function during this period. These responses center around circulatory adjustments that ensure adequate perfusion of the brain and heart, and require autonomous secretion of catecholamines from the adrenal medulla (102), as well as a myocardium that is adapted to function in a low oxygen environment. $(103,104)$ Prenatal nicotine exposure leads to severe reduction or loss of the adrenomedullary component, along with a reduced cardiac response to adrenergic stimulation, resulting in brain injury or death during a hypoxic episode that would ordinarily not be harmful. $(59,60,105)$ Although animal studies provide the primary evidence for this mechanism, the same deficiency in adrenomedullary function in response to hypoxia has been identified in the offspring of smokers at birth.(106) The loss of cardiovascular adaptation caused by maternal smoking affects the fetus during delivery, when hypoxic events can evoke stillbirth or birth asphyxia, as well as during infancy, when hypoxic events can result in SIDS.(107)

Additional contributions of maternal smoking to SIDS risk likely entail effects on central cardiorespiratory control and arousal. Maturation of sleep architecture and sleep during the first year of life includes changes in both respiratory and cardiovascular control.(108) Infants, especially those born preterm, are at increased risk for cardiorespiratory disturbances, apnea, and hypoxemia during sleep, events for which arousal is an important protective response. Failure of this response mechanism could contribute to SIDS risk. (109-111) Maternal smoking and smokeless tobacco use during pregnancy are associated with increased risk of neonatal apnea, while maternal smoking is also associated with a decreased arousal response.(109, 112-118) The administration of nicotine to pregnant ewes can evoke the same deficit in newborn lambs.(119) In addition, there is evidence that prenatal nicotine exposure damages brainstem circuits that are responsible for mounting 
appropriate respiratory responses to neonatal hypoxia, which could contribute to additional SIDS risk. $(120,121)$

\subsection{Infant stress response}

Maternal smoking during pregnancy in humans leads to alterations in behavior and stress responsiveness in newborns, in addition to the specific effects on hypoxic stress discussed above. Specifically, studies of the immediate neonatal period (postnatal days 1-5) revealed increased signs of abstinence/withdrawal, hypertonicity, irritability, and excitability in tobacco-exposed neonates, with a clear dose-response relationship to nicotine exposure. (122-126) Studies later in the neonatal period (10-30 days) found continued or emerging behavioral effects on self-regulation, attention, need for external soothing or handling, and arousal-all potentially portending longer-term effects on attention and regulation.(127-129) Several studies also found alterations in stress responses in exposed infants. For example, the stress hormone, cortisol, was increased in the cord blood of newborns of smoking mothers,(130-132) and infants aged 1-7 months showed altered cortisol response to stress. (133-135) There is extensive scientific literature on the long-term neurobehavioral deficits associated with early life exposure to prolonged stress and/or excessive glucocorticoid hormones (reviewed by Maccari et al, 2003).(136) Similarly, animal studies found evidence that prenatal nicotine exposure disrupts stress hormone regulation in offspring.(137-139) For example, in one study, adult male rats with gestational exposure to nicotine showed abnormal neuroendocrine responses to stress.(137)

\subsection{Auditory processing}

A number of studies have examined maternal smoking and infant auditory processing. (140-143) Healthy newborn infants of non-smoking mothers discriminated among a greater number of syllables whereas healthy newborns of smokers began the discrimination process at least $150 \mathrm{msec}$ later and differentiated fewer stimuli.(144) Effects on auditory processing may persist beyond infancy; an increased risk of low-frequency hearing loss has been documented in adolescent offspring of women who smoked during pregnancy.(145) Animal research supports that nicotine adversely affects auditory processing. $(71,146)$ Exposure of rats to nicotine in the second postnatal week, corresponding to the third trimester of human fetal brain development,(147) disrupted the development of glutamate synapses in the auditory cortex, which has been associated with long-term deficits in auditory processing and learning.(67, 71$)$

\subsection{Outcomes in childhood and adolescence}

Numerous studies have addressed the long-term consequences of maternal smoking during pregnancy on offspring behavior. The most consistent associations are with externalizing and disruptive behaviors, such as conduct disorder (antisocial personality disorder in adults) and oppositional defiant disorder, from infancy through adulthood, as well as the precursors of these behaviors. $(148,149)$ However, a major limitation of traditional approaches to studies of prenatal tobacco exposure and behavioral outcomes has been the inability to fully control for potential confounding factors, particularly family environment and genetic factors.(150) More recently, high quality, prospective studies using multimethod exposure measurement and propensity score modeling have delineated a coherent pattern of disruptive behavior 
associated with prenatal tobacco exposure, beginning in early childhood.(151,152) For example, adoption studies provide support for an independent effect of maternal smoking during pregnancy on externalizing behaviors.(151) A recent sibling study that included detailed exposure data and careful control for family-level effects found modest, but statistically significant associations between tobacco exposure and conduct disorder symptoms and oppositional defiant disorder symptoms.(153) Both associations were similar in magnitude to contributions from genetics and family environment described in prior work. These studies add evidence supporting a role for prenatal tobacco exposure in increased risk for externalizing behaviors.

Associations have also been described between maternal smoking during pregnancy and offspring internalizing behaviors (anxiety and depression), attention deficit hyperactivity disorder (ADHD), and impairments in learning and memory, but are less consistent than for externalizing behaviors.(150,154-176) These inconsistencies illustrate the difficulty in determining cause-and-effect relationships for different outcomes in diverse human populations with multiple confounders and risk factors for neurobehavioral deficits, especially when the associated behavior may not emerge for years after the injurious exposure.

Animal models have been used to assess the role of prenatal nicotine exposure on developmental and long-term behavioral outcomes. Reflex behaviors characterize the development of sensory and motor systems in the brain, and rodent studies suggest that prenatal nicotine exposure delays maturation of reflexes, including negative geotaxis and surface righting (measures of limb coordination and locomotor development), as well as causing long-lasting alterations in filtering auditory information. (146, 177-179) However, these findings are not entirely consistent; some studies found normal reflex development in exposed animals (reviewed by Sobrian and Holson 2011).(180) Activity levels have also been studied using rodent models, again with inconsistent results, perhaps reflecting differences in the developmental exposure period and the method of nicotine administration, or, in some cases, lack of sufficient statistical power in the experimental design.(180)

In contrast, there is greater consistency among animal studies examining the effects of prenatal nicotine exposure on cognitive development, suggestive of global impairments in learning and memory.(181-190) These effects appear to be dose dependent and sensitive to factors such as sex and timing of exposure. Research suggests that these deficits reflect effects on nAChR modulation of long-term potentiation in the hippocampus.(187) Adverse outcomes on affective behavior have also been identified, including learned helplessness, fear trace conditioning, and anhedonia. $(191,192)$ Combined gestational/neonatal exposure is associated with increased anxiety levels, poor adaptation in a new environment, and decreased novelty-seeking. $(181,193,194)$

\subsection{Pulmonary outcomes}

Maternal smoking during pregnancy has adverse effects outside the central nervous system, most notably on lung development, causing lifelong decreases in pulmonary function. (195-199) At birth, and prior to any significant postnatal exposure to tobacco smoke, infants born to smokers show decreased pulmonary function tests, with decreased respiratory flows 
and respiratory compliance, and altered tidal breathing patterns. (198-200) These changes lead to increased risk in childhood of wheezing, hospitalization for respiratory infections, and asthma.(201-203) Studies of the effects of nicotine on lung development have been performed in mice, rats, sheep and monkeys with strikingly similar results between animals and humans.(204) In humans, the clearest, most consistently measured effect of maternal smoking during pregnancy on offspring respiratory health is decreased forced expiratory flow.(195-198) In both monkeys and mice, exposure to prenatal nicotine alone, at levels similar to that of smokers, causes similar decreases in forced expiratory flow.(205-207) A primary mediator of this effect appears to be the a $7 \mathrm{nAChR}$, as the effect of nicotine was lost in a 7 nAChR knockout mice.(205)

Studies on non-human primates point to the potential mechanisms of nicotine's actions on lung development. Treatment of pregnant rhesus monkeys with nicotine causes marked increases of levels of a $7 \mathrm{nAChR}$ in fibroblasts surrounding airways and blood vessels in the fetal monkey lung, and increases in collagen in a similar distribution.(208-210) Similar effects are seen in mice.(205) The increased collagen and decreased elastin caused by prenatal nicotine exposure likely underlies the decreases in lung compliance seen in the offspring of smokers. Prenatal nicotine exposure leads to thickening of walls surrounding airways and pulmonary vessels in animal models, $(209,210)$ a finding that has also been reported in the human offspring of smokers, $(211,212)$ along with similar increases in connective tissue and a 7 expression.(212) In addition, consistent with the long term effects on offspring pulmonary function and increased risk of asthma associated with maternal smoking during pregnancy in humans, smoking during pregnancy causes long-lasting changes in DNA methylation if offspring(213) that are observed in fetal lung,(214) cord blood,(214) and which continue to be present in the blood of school-age children.(215) In rodent models, prenatal nicotine exposure causes similar DNA methylation changes, including changes in Runx1 methylation, which has been associated with increased risk of asthma,(216-219) Research by Rehan and colleagues supports that DNA methylation changes caused by in utero nicotine exposure may persist for multiple generations.(217, 218) Rodent models also suggest that prenatal tobacco exposure can cause decreased histone deacetylate activity in offspring lung, accompanied by changes in expression of the glucocorticoid receptor splice variant 1.7.(220) While the immediate human clinical impact of these findings are unclear, they suggest that epigenomic modifications in important inflammatory and pulmonary maturation pathways (i.e., glucocorticoid receptors), may result from in utero nicotine exposure. Whether this ultimately translates into increased risk of asthma and pulmonary atopic disease among offspring remains unknown.

\section{Tobacco use and nicotine exposure during adolescence}

\subsection{Tobacco use during adolescence}

Tobacco use among adolescents in the United States is changing rapidly. While the prevalence of cigarette smoking has steadily declined over the past decade(18, 221-223), the use of alternative tobacco products, including electronic cigarettes, has increased.(224) Conventional cigarettes were the most commonly used tobacco products by U.S. youth in 2013 (225), and many youth who used electronic cigarettes - more than a quarter million- 
had never smoked combustible cigarettes (226). A subsequent survey in 2014 and 2015 found that past-month e-cigarette use has surpassed conventional cigarette use among middle and high school students. $(227,228)$ Several longitudinal studies have found that electronic cigarette use at baseline is associated with increased risk of future use of combustible tobacco products. $(9,10,229,230)$

\subsection{Brain development in adolescence}

Concerns about nicotine toxicity do not end after birth or infancy. Brain development continues well into the third decade of life, and the adolescent and young adult brains differ from those of the fully mature adult, both physiologically and neurochemically. For example, adolescent synapses are more numerous and more "plastic," or moldable by experience.(231-233) Hence, adolescents have superior learning and memory skills compared to adults, with synaptic formation and learning highly strengthened by stimulation from environmental experience.(234) This feature of adolescent brain development can have detrimental consequences when inappropriate stimulation is evoked by exposure to neuroactive chemicals. For example, addictive stimuli or drugs can activate and strengthen reward circuits to create an addicted state.(235) Adolescents and young adults are thus more vulnerable to addiction than adults.(223) In support of this, epidemiologic studies document that individuals who begin smoking as teens are more likely to become life-long smokers than those who start smoking in their 20's or later.(236-238) Furthermore, adolescents experience symptoms of dependence at lower levels of nicotine exposure than adults. (239-241) Consequently, it is harder to reverse addiction originating in this stage compared with later in life.(242) Animal studies confirm the heightened response of adolescents to nicotine exposure.(243) Adolescent rodents self-administer nicotine more than adults and adolescent exposure leads to increased self-administration of nicotine (244) and other drugs in adulthood.(245)

The special vulnerability of the adolescent brain extends to areas involved in higher cognitive function, such as the prefrontal cortex where circuit formation continues into the 20s. During this extended maturational period, substantial neural remodeling occurs in a variety of pathways, including those governed by dopamine or acetylcholine. Dopamine is critical to reward function, and acetylcholine plays a central role in cognitive maturation, including executive function mediated by the prefrontal cortex.(246)

Functional magnetic resonance imaging (fMRI) has been used in numerous studies of adult smokers to examine the neural circuitry involved in nicotine craving and addiction,(247-255) but in fewer studies of adolescent smokers.(256-261) Peters et al. examined neural responses to anticipation of financial reward in adolescent smokers (age 14 years)(262) and found that they had smaller neural responses in the ventral striatum and midbrain compared to matched non-smoking controls. Moreover, the reduced response showed a clear-cut relationship with the frequency of smoking. These findings suggest that adolescent smokers display a hyporesponsivity to the anticipation of non-drug reward (i.e., financial reward) relative to nonsmokers, and this hypo-responsivity becomes more severe with increased smoking. There is also evidence that adolescents who smoke $\mathbf{5}$ cigarettes per day display attenuated responses to other non-drug rewards, including pleasurable food images, relative to non-smokers, in 
areas including the insula and inferior frontal region.(256) The implication of both these studies is that the use of extremely rewarding drugs, such as nicotine, may decrease the perception of the pleasure obtained from non-drug rewards. Furthermore, the fact that this was demonstrated in young- and light-smoking teens indicates that such changes in the brain occur in early phases of smoking.

\subsection{Cognitive outcomes}

Nicotine withdrawal produces transient cognitive impairment and negative affective states, while smoking relapse alleviates these symptoms (reviewed by Hall et al., 2015).(263) In addition, adult smokers show more rapid cognitive decline with age than nonsmokers, (264-268) although it is unclear whether the underlying mechanisms involve nicotine, products of combustion, or both.(15) The few studies that have been done in adolescents and young adults also suggest that cigarette smoking has adverse effects on cognition.(269-271) For example, one study found that current smokers aged 17-21 who smoked throughout their adolescence performed significantly worse than their nonsmoking counterparts on a variety of neurocognitive tasks, even after adjustment for educational attainment and family income. (271) In a separate study of adolescent daily smokers and nonsmokers who were similar in age, sex, and education, smokers showed impairments in accuracy of working memory performance, irrespective of recency of smoking.(269) Earlier age at onset of smoking was associated with more severe performance decrements, and smokers experienced depressed mood and further disruption of working memory and verbal memory during abstinence. Furthermore, male smokers initiated smoking at an earlier age than females and were more impaired during tests of selective and divided attention than female smokers and nonsmokers. Abstinent adolescent smokers have also been found to exhibit reductions in the efficiency of their working memory neurocircuitry.(270) In a study of adolescent smokers and non-smokers who were similar with respect to age, education, IQ, parental education, and symptoms of inattention, prenatal and adolescent exposure to tobacco smoke were both associated with increased fractional anisotropy in anterior cortical white matter.(258) Disruption of auditory corticofugal fibers may interfere with the ability of these fibers to modulate ascending auditory signals, leading to greater noise and reduced efficiency of neurocircuitry that supports auditory processing. In a study of young adult non-abstinent smokers and non-smokers age 18-29 years who were matched for age, education, income, and sex, smokers showed significant cognitive impairments in sustained attention, spatial working memory, and executive planning.(272) In a study of young adults age 18-35 years, the authors found prefrontal attentional network activity was reduced in smokers compared with non-smokers using fMRI, and the degree of diminished attentional network activity was correlated with the number of years participants had smoked.(273) Finally, cognitive deficits have also been associated with childhood and adolescent exposure to secondhand cigarette smoke. $(274,275)$

The association between adolescent cigarette smoking and long-lasting deficits in cognition is especially troubling because several mental health disorders that include changes in cognition are also associated with higher rates of tobacco use.(276-283) For example, an elevated prevalence of cigarette smoking has been noted among individuals with schizophrenia, ADHD, depression, anxiety disorders, bipolar disorder, and others. $(284,285)$ 
There is evidence to support a bidirectional relationship—attributes that predispose individuals to these conditions could also predispose them to tobacco use and nicotine useand addiction could result in or exacerbate symptoms accompanying these disorders.(263, 286) Similar phenomena could occur in individuals with subclinical affective or cognitive disorders.(263)

Existing human studies of cognitive outcomes are mainly cross-sectional in nature, making it difficult to determine whether tobacco use results from premorbid cognitive problems or causes these problems. However, studies of laboratory rodents provide strong evidence that isolated nicotine exposure during adolescence produces long-lasting deficits in learning and cognitive processes.(182, 287-290) For example, adolescent nicotine exposure was associated with adult deficits in contextual fear conditioning, but not cued fear conditioning, in both rats and mice,(288) suggesting altered function in brain regions involved in contextual processing, such as the hippocampus. In support of altered hippocampal function, adolescent nicotine exposure was associated with reduced hippocampal CA1 dendritic length and apical dendritic branch complexity. (291) The effects on learning were not seen in adults similarly exposed to nicotine.(182) In addition, adult rats exposed to nicotine during adolescence had deficits in attention and displayed increased impulsivity.(292) These cognitive deficits may be related to long-lasting changes in cellular processes involved in synaptic plasticity, as adolescent nicotine exposure altered adult medial prefrontal cortical long-term potentiation of synaptic activity.(289)

Animal studies also provide evidence for long-lasting changes in mental health-related behaviors after adolescent nicotine exposure.(293-295) For example, adolescent nicotine exposure increased anxiety in adult rats,(296) decreased the sensitivity to natural rewards, and fostered depression-like behaviors.(295) Further, changes in anxiety related to adolescent nicotine exposure were associated with increased corticotropin-releasing factor, a neuropeptide involved in stress response initiation, in the hypothalamus and frontal cortex and frontal cortex and increased neuropeptide $\mathrm{Y}$, a neuropeptide that may play a protective role in responses to stress, in the hypothalamus and hippocampus.(297) Together, these findings raise serious concerns about the long-term impact of adolescent nicotine exposure on mental health through adverse effects on cognition, anxiety, impulsivity, depression, and drug reward and reinforcement.

\subsection{Trajectory of tobacco and other substances use}

There is evidence that nicotine exposure in adolescence affects the use of other substances. In the U.S. population, the use of tobacco often precedes the use of other drugs including marijuana, which in turn generally precedes the use of cocaine and other illicit substances for those who go on to use other drugs.(298-300) Although this pattern may reflect that tobacco is legal and easier to access than illicit substances, evidence from translational research in rodents supports a causal mechanism for the observed sequence of progression from tobacco to other drugs. Nicotine pretreatment in mice and rats enhances the subsequent response to cocaine, but the effect is unidirectional, as the reverse order (cocaine followed by nicotine) does not result in enhancement of the response to nicotine.(301-303) At the molecular level, nicotine exerts a priming effect by enhancing the ability of cocaine to 
induce $F o s B$, a key mediator of addiction. $(304,305)$ It does so by inhibiting histone deacetylation. The consequent enhancement of gene expression leads to an increase in the response to cocaine in reward-based areas. These results provide a biological basis and a molecular mechanism for nicotine as a gateway drug.

\section{Synthesis and conclusions}

Historically, many clinicians and scientists have considered exposure to nicotine alone to be low risk, especially for established smokers. However, for pregnant women and adolescents, a large body of scientific evidence challenges this concept. As detailed in this review, existing human and animal research provides sufficient evidence for researchers and public health officials to draw a number of conclusions regarding the adverse effects of nicotine on human development. These conclusions could serve as a foundation for public health policy, planning, and practice regarding electronic cigarettes and other non-combustible tobacco products.

Animal models of prenatal nicotine exposure have successfully recapitulated the neurodevelopmental and behavioral phenotypes associated with maternal cigarette smoking during pregnancy, $(55-57,64,306)$ and these studies show that nicotine itself is a critical contributor to the harmful neurodevelopmental effects of tobacco smoke exposure.(307-310) Similarly, the combined results from animal and human studies of prenatal cigarette and nicotine exposure provide consistent evidence that fetal nicotine exposure adversely affects lung development in utero, in infancy, and in childhood.(204) It is likely that the use of nicotine-containing products by pregnant women, including electronic cigarettes, will have effects on pulmonary development that are similar to those observed in the offspring of cigarette smokers. While there is evidence of variability in nicotine delivery across devices and users, $(311,312)$ evidence suggests that some electronic cigarette products may deliver as much nicotine as conventional cigarettes. $(313,314)$ Because lung development in utero and in childhood contributes to life-long trajectories of lung function, the effects of prenatal exposure to nicotine could have negative effects on respiratory health in middle-aged and older adults, including increased risk of asthma and chronic obstructive pulmonary disease (COPD).(315-317) In addition, human and animal studies of prenatal tobacco and nicotine effects on cardiorespiratory function provide strong evidence that fetal nicotine exposure compromises the fetal and neonatal response to hypoxic stress, which could contribute to the pathophysiology underlying SIDS.

The integration of human and animal studies of behavioral and cognitive outcomes associated with nicotine exposure is complex, but also demonstrates areas of close alignment. Maternal cigarette smoking in humans and nicotine exposure in animals have been consistently associated with auditory processing deficits, which could affect language development and speech comprehension. Rigorous studies of prenatal tobacco exposure in humans using innovative approaches to address potential confounding from genetic and environmental factors have found associations with externalizing behavioral outcomes in offspring. Furthermore, animal studies of gestational nicotine exposure provide support for the underlying biological mechanisms that could explain deficits observed in humans, 
notably nicotine's actions on nAChRs. nAChRs play unique roles in development, and exposure to nicotine, even at very low levels, disrupts those developmental processes.

Human and animal studies of adolescent exposure to cigarette smoking and nicotine also have areas of convergence. It is well established from human and animal research that adolescents are highly vulnerable to addiction to nicotine.(223) More recent animal studies demonstrate a "priming" effect of nicotine that increases vulnerability to addiction to other drugs. Studies of human adolescent smokers also find deficits in working memory, attention, and auditory processing, and adolescent nicotine exposure in rodents is associated with deficits in learning and in attention, as well as in increased impulsivity and anxiety. Prospective studies of child and adolescent drug exposure, such as the recently launched Adolescent Brain Cognitive Development Study,(318) could yield additional data from subjects exposed to non-combustible tobacco products, such as smokeless tobacco and electronic cigarettes, helping to quantify the effects of nicotine exposure on cognitive, behavioral, and mental health outcomes. Finally, nicotine withdrawal in adolescent tobacco users can cause impairments in cognition and has adverse effects on mood and attention. (269-271)

The evidence presented in this review has often been overlooked in discussions about the relative harms and risks of electronic cigarettes, perhaps in part because of the paucity of studies of isolated nicotine exposure in humans. Randomized trials of nicotine exposure in humans that could determine effects of nicotine on development are unethical, so researchers rely on observational studies of human smokers. Human smokers, however, are exposed not only to nicotine, but to hundreds of other toxic components generated by combustion, such as carbon monoxide, acetaldehyde, and polycyclic aromatic hydrocarbons. In addition, there are numerous methodological challenges inherent in studies of smokers, including residual confounding from socioeconomic, environmental, genetic and other factors. Although considerable progress has been made in overcoming these limitations, controlled animal experiments remain a critically important supplement to human studies in establishing the consequences of nicotine exposure. In fact, rodent models historically have served as the "gold standard" for evaluating developmental neurotoxicants, $(64,319)$ and regulatory decisions on product safety are routinely made using animal data. Of particular relevance to nicotine is the example of chlorpyrifos, an acetylcholinesterase inhibitor and widely-used organophosphate insecticide that leads to inappropriate overstimulation of cholinergic receptors similar to that caused by nicotine. $(57)^{1}$

Despite the strength of data in support of adverse effects of nicotine exposure during pregnancy and adolescence, important research gaps remain that, if addressed, could better characterize these effects. An improved understanding of how the timing of nicotine exposure during pregnancy affects fetal development could lead to more effective strategies to limit nicotine's effects, such as intensified efforts to promote cessation by a specific gestational age or prior to conception. Research could also expand our understanding of the

\footnotetext{
${ }^{1}$ In 2002, chlorpyrifos was banned from residential use by the US Environmental Protection Agency based almost entirely on neurodevelopmental deficits demonstrated in rodent studies that were explicitly modeled after those conducted for nicotine.(57, 64, 320)
} 
relative contributions of nicotine and products of combustion to effects on brain development and cognitive outcomes in adolescence. Indeed, several recent studies indicate that other tobacco smoke components amplify the adverse effects of nicotine, and that even the low levels of nicotine exposure associated with secondhand smoke are injurious to fetal brain development and cognitive function. $(79,321,322)$

Recently, important steps were taken that will help protect vulnerable populations from exposure to nicotine. The Child Nicotine Poisoning Prevention Act, which requires childresistant containers for liquid nicotine e-cigarette cartridges, was signed into law in February 2016.(323) In May 2016, the U.S. Food and Drug Administration finalized a rule extending its authority to all tobacco products, including electronic cigarettes. Federal law will require health warnings on electronic cigarette packages and advertisements that read "WARNING: This product contains nicotine. Nicotine is an addictive chemical." The law prohibits the sale of electronic cigarettes to individuals under the age of 18 years, the sale of electronic cigarettes in vending machines, and the distribution of free samples.(324) In the future, additional potentially effective strategies could include strong prohibitions on electronic cigarette marketing to reduce youth uptake, health warnings specific to pregnant women and adolescents, and protection from exposure to secondhand electronic cigarette aerosol. Measures could also include consideration of the impact of pricing on youth initiation and use; product addiction potential and youth appeal, including youth-oriented flavorings; accessibility of products through placement in retail venues; and social networking potential. In addition, policies related to the age of legal sale of electronic cigarettes and other nicotine-containing products could benefit if informed by our knowledge of the developmental stages during which humans are most vulnerable to the adverse effects of nicotine. Because the brain does not reach full maturity until the mid-20s,(325) restricting sales of electronic cigarettes and all tobacco products to individuals aged at least 21 years and older could have positive health benefits for adolescents and young adults. Finally, it is important for clinicians to deliver a clear message that nicotine adversely affects health by providing unequivocal advice to pregnant women and adolescents to avoid the use of all tobacco products, as well as exposure to both secondhand smoke and secondhand aerosol. If these measures are accompanied by intensification of established comprehensive tobacco control programs as recommended by CDC,(326) they would be expected to have an even greater impact.

\section{References}

1. Aguinaga Bialous S, Peeters S. A brief overview of the tobacco industry in the last 20 years. Tob Control. 2012; 21(2):92-4. [PubMed: 22345228]

2. Newswire P. [25 August 2016] Reynolds American Inc. Completes acquisition of niconovum ab. 2009. http://www.prnewswire.com/news-releases/reynolds-american-inc-completes-acquisition-ofniconovum-ab-78862587.html

3. Kostygina G, England L, Ling P. New product marketing blurs the line between nicotine replacement therapy and smokeless tobacco products. Am J Public Health. 2016; 106(7):1219-22. [PubMed: 27077338]

4. Grana R, Benowitz N, Glantz SA. E-cigarettes: A scientific review. Circulation. 2014; 129(19): 1972-86. [PubMed: 24821826] 
5. Singh T, Arrazola RA, Corey CG, Husten CG, Neff LJ, Homa DM, et al. Tobacco use among middle and high school students - united states, 2011-2015. MMWR Morb Mortal Wkly Rep. 2016; 65(14): 361-7. [PubMed: 27077789]

6. King BA, Patel R, Nguyen KH, Dube SR. Trends in awareness and use of electronic cigarettes among us adults, 2010-2013. Nicotine Tob Res. 2015; 17(2):219-27. [PubMed: 25239961]

7. Etter JF. Should electronic cigarettes be as freely available as tobacco? Yes. BMJ. 2013; 346:f3845. [PubMed: 23771039]

8. Chapman S. Should electronic cigarettes be as freely available as tobacco cigarettes? No. BMJ. 2013; 346:f3840. [PubMed: 23771038]

9. Primack BA, Soneji S, Stoolmiller M, Fine MJ, Sargent JD. Progression to traditional cigarette smoking after electronic cigarette use among us adolescents and young adults. JAMA Pediatr. 2015; 169(11):1018-23. [PubMed: 26348249]

10. Leventhal AM, Strong DR, Kirkpatrick MG, Unger JB, Sussman S, Riggs NR, et al. Association of electronic cigarette use with initiation of combustible tobacco product smoking in early adolescence. JAMA. 2015; 314(7):700-7. [PubMed: 26284721]

11. Wagener TL, Siegel M, Borrelli B. Electronic cigarettes: Achieving a balanced perspective. Addiction. 2012; 107(9):1545-8. [PubMed: 22471757]

12. Fagerstrom KO, Bridgman K. Tobacco harm reduction: The need for new products that can compete with cigarettes. Addict Behav. 2014; 39(3):507-11. [PubMed: 24290207]

13. Piano MR, Benowitz NL, Fitzgerald GA, Corbridge S, Heath J, Hahn E, et al. Impact of smokeless tobacco products on cardiovascular disease: Implications for policy, prevention, and treatment: A policy statement from the american heart association. Circulation. 2010; 122(15):1520-44. [PubMed: 20837898]

14. Boffetta P, Straif K. Use of smokeless tobacco and risk of myocardial infarction and stroke: Systematic review with meta-analysis. BMJ. 2009; 339:b3060. [PubMed: 19690343]

15. U.S. Department of Health and Human Services. The health consequences of smoking: 50 years of progress A report of the Surgeon General. U.S Department of Health and Human Services, Centers for Disease Control and Prevention, National Center for Chronic Disease Prevention and Health Promotion, Office on Smoking and Health; 2014.

16. Boffetta P, Aagnes B, Weiderpass E, Andersen A. Smokeless tobacco use and risk of cancer of the pancreas and other organs. Int J Cancer. 2005; 114(6):992-5. [PubMed: 15645430]

17. Collaco JM, Drummond M, McGrath-Morrow SA. Electronic cigarette use and exposure in the pediatric population. JAMA Pediatr. 2015; 169(2):177-182. [PubMed: 25546699]

18. Lee YO, Hebert CJ, Nonnemaker JM, Kim AE. Youth tobacco product use in the united states. Pediatrics. 2015; 135(3):409-15. [PubMed: 25647680]

19. Ojeda N, Hall S, Lasley CJ, Rudsenske B, Dixit M, Arany I. Prenatal nicotine exposure augments renal oxidative stress in embryos of pregnant rats with reduced uterine perfusion pressure. In Vivo. 2016; 30(3):219-24. [PubMed: 27107078]

20. Shariati Kohbanani M, Taghavi MM, Shabanizadeh A, Jafari Naveh HR, Taghipour Z, Kazemi Arababadi M. Different ideas associated renal malformation and laminin alpha5 expression caused by maternal nicotine exposures. Cell Mol Biol. 2016; 62(3):100-4.

21. Chen CM, Chou HC, Huang LT. Maternal nicotine exposure during gestation and lactation induces kidney injury and fibrosis in rat offspring. Pediatr Res. 2015; 77(1-1):56-63. [PubMed: 25279991]

22. Serobyan N, Orlovskaya I, Kozlov V, Khaldoyanidi SK. Exposure to nicotine during gestation interferes with the colonization of fetal bone marrow by hematopoietic stem/progenitor cells. Stem Cells Dev. 2005; 14(1):81-91. [PubMed: 15725747]

23. Somm E. Nicotinic cholinergic signaling in adipose tissue and pancreatic islets biology: Revisited function and therapeutic perspectives. Arch Immunol Ther Exp. 2014; 62(2):87-101.

24. Sussan TE, Gajghate S, Thimmulappa RK, Ma J, Kim JH, Sudini K, et al. Exposure to electronic cigarettes impairs pulmonary anti-bacterial and anti-viral defenses in a mouse model. PloS One. 2015; 10(2):e0116861. [PubMed: 25651083]

25. Lerner CA, Sundar IK, Yao H, Gerloff J, Ossip DJ, McIntosh S, et al. Vapors produced by electronic cigarettes and e-juices with flavorings induce toxicity, oxidative stress, and 
inflammatory response in lung epithelial cells and in mouse lung. PloS One. 2015; 10(2):e0116732. [PubMed: 25658421]

26. Garcia-Arcos I, Geraghty P, Baumlin N, Campos M, Dabo AJ, Jundi B, et al. Chronic electronic cigarette exposure in mice induces features of copd in a nicotine-dependent manner. Thorax. 2016

27. Ponzoni L, Moretti M, Sala M, Fasoli F, Mucchietto V, Lucini V, et al. Different physiological and behavioural effects of e-cigarette vapour and cigarette smoke in mice. Eur Neuropsychopharmacol. 2015; 25(10):1775-86. [PubMed: 26141510]

28. Polen KN, Sandhu PK, Honein MA, Green KK, Berkowitz JM, Pace J, et al. Knowledge and attitudes of adults towards smoking in pregnancy: Results from the healthstyles(c) 2008 survey. Matern Child Health J. 2015; 19(1):144-54. [PubMed: 24825031]

29. Tong VT, Dietz PM, Morrow B, D’Angelo DV, Farr SL, Rockhill KM, et al. Trends in smoking before, during, and after pregnancy--pregnancy risk assessment monitoring system, united states, 40 sites, 2000-2010. MMWR Surveill Summ summaries. 2013; 62(6):1-19.

30. U.S. Department of Health and Human Services. How Tobacco Smoke Causes Disease: The Biology and Behavioral Basis for Smoking-Attributable Disease: A Report of the Surgeon general. Atlanta, GA: U.S Department of Health and Human Services, Centers for Disease Control and Prevention, National Center for Chronic Disease Prevention and Health Promotion; 2010.

31. Gupta PC, Subramoney S. Smokeless tobacco use and risk of stillbirth: A cohort study in Mumbai, India. Epidemiology. 2006; 17(1):47-51. [PubMed: 16357594]

32. Baba S, Wikstrom AK, Stephansson O, Cnattingius S. Influence of smoking and snuff cessation on risk of preterm birth. Eur J Epidemiol. 2012; 27(4):297-304. [PubMed: 22430122]

33. Wikstrom AK, Cnattingius S, Stephansson O. Maternal use of swedish snuff (snus) and risk of stillbirth. Epidemiology. 2010; 21(6):772-8. [PubMed: 20805750]

34. England LJ, Kim SY, Shapiro-Mendoza CK, Wilson HG, Kendrick JS, Satten GA, et al. Effects of maternal smokeless tobacco use on selected pregnancy outcomes in Alaska Native women: A casecontrol study. Acta Obstet Gynecol Scand. 2013; 92(6):648-55. [PubMed: 23551054]

35. Gunnerbeck A, Edstedt Bonamy AK, Wikstrom AK, Granath F, Wickstrom R, Cnattingius S. Maternal snuff use and smoking and the risk of oral cleft malformations--a population-based cohort study. PloS One. 2014; 9(1):e84715. [PubMed: 24454740]

36. Baba S, Wikstrom AK, Stephansson O, Cnattingius S. Changes in snuff and smoking habits in swedish pregnant women and risk for small for gestational age births. BJOG. 2013; 120(4):45662. [PubMed: 23190416]

37. England LJ, Levine RJ, Mills JL, Klebanoff MA, Yu KF, Cnattingius S. Adverse pregnancy outcomes in snuff users. Am J Obstet Gynecol. 2003; 189(4):939-43. [PubMed: 14586330]

38. Juarez SP, Merlo J. The effect of swedish snuff (snus) on offspring birthweight: A sibling analysis. PloS One. 2013; 8(6):e65611. [PubMed: 23776512]

39. England LJ, Kim SY, Shapiro-Mendoza CK, Wilson HG, Kendrick JS, Satten GA, et al. Maternal smokeless tobacco use in Alaska Native women and singleton infant birth size. Acta Obstet Gynecol Scand. 2012; 91(1):93-103. [PubMed: 21902677]

40. Navarro HA, Seidler FJ, Schwartz RD, Baker FE, Dobbins SS, Slotkin TA. Prenatal exposure to nicotine impairs nervous system development at a dose which does not affect viability or growth. Brain Res Bull. 1989; 23(3):187-92. [PubMed: 2819477]

41. Birnbaum SC, Kien N, Martucci RW, Gelzleichter TR, Witschi H, Hendrickx AG, et al. Nicotineor epinephrine-induced uteroplacental vasoconstriction and fetal growth in the rat. Toxicology. 1994; 94(1-3):69-80. [PubMed: 7801331]

42. Hussein J, Farkas S, MacKinnon Y, Ariano RE, Sitar DS, Hasan SU. Nicotine dose-concentration relationship and pregnancy outcomes in rat: Biologic plausibility and implications for future research. Toxicol Appl Pharmacol. 2007; 218(1):1-10. [PubMed: 17141291]

43. Lauder JM. Roles for neurotransmitters in development: Possible interaction with drugs during the fetal and neonatal periods. Prog Clin Biol Res. 1985; 163c:375-80. [PubMed: 2859601]

44. Whitaker-Azmitia PM. Role of serotonin and other neurotransmitter receptors in brain development: Basis for developmental pharmacology. Pharmacol Rev. 1991; 43(4):553-61. [PubMed: 1663620] 
45. Luck W, Nau H, Hansen R, Steldinger R. Extent of nicotine and cotinine transfer to the human fetus, placenta and amniotic fluid of smoking mothers. Dev Pharmacol Ther. 1985; 8(6):384-95. [PubMed: 4075937]

46. Cairns NJ, Wonnacott S. [3h](-)nicotine binding sites in fetal human brain. Brain Res. 1988; 475(1):1-7. [PubMed: 3214718]

47. Hagino N, Lee JW. Effect of maternal nicotine on the development of sites for [(3)h]nicotine binding in the fetal brain. Int J Dev Neurosci. 1985; 3(5):567-71. [PubMed: 24874966]

48. Dwyer JB, Broide RS, Leslie FM. Nicotine and brain development. Birth Defects Res C Embryo Today. 2008; 84(1):30-44. [PubMed: 18383130]

49. Atluri P, Fleck MW, Shen Q, Mah SJ, Stadfelt D, Barnes W, et al. Functional nicotinic acetylcholine receptor expression in stem and progenitor cells of the early embryonic mouse cerebral cortex. Dev Biol. 2001; 240(1):143-56. [PubMed: 11784052]

50. Schneider AS, Atluri P, Shen Q, Barnes W, Mah SJ, Stadfelt D, et al. Functional nicotinic acetylcholine receptor expression on stem and progenitor cells of the early embryonic nervous system. Ann N Y Acad Sci. 2002; 971:135-8. [PubMed: 12438103]

51. Roy TS, Andrews JE, Seidler FJ, Slotkin TA. Nicotine evokes cell death in embryonic rat brain during neurulation. The Journal of pharmacology and experimental therapeutics. 1998; 287(3): 1136-44. [PubMed: 9864303]

52. Roy TS, Seidler FJ, Slotkin TA. Prenatal nicotine exposure evokes alterations of cell structure in hippocampus and somatosensory cortex. J Pharmacol Exp Ther. 2002; 300(1):124-33. [PubMed: 11752107]

53. Roy TS, Sabherwal U. Effects of gestational nicotine exposure on hippocampal morphology. Neurotoxicol Teratol. 1998; 20(4):465-73. [PubMed: 9697973]

54. Roy TS, Sabherwal U. Effects of prenatal nicotine exposure on the morphogenesis of somatosensory cortex. Neurotoxicol Teratol. 1994; 16(4):411-21. [PubMed: 7968943]

55. Slotkin TA. If nicotine is a developmental neurotoxicant in animal studies, dare we recommend nicotine replacement therapy in pregnant women and adolescents? Neurotoxicol Teratol. 2008; 30(1):1-19. [PubMed: 18380035]

56. Pauly JR, Slotkin TA. Maternal tobacco smoking, nicotine replacement and neurobehavioural development. Acta Paediatr. 2008; 97(10):1331-7. [PubMed: 18554275]

57. Slotkin TA. Developmental cholinotoxicants: Nicotine and chlorpyrifos. Environ Health Perspect. 1999; 107(Suppl 1):71-80. [PubMed: 10229709]

58. Slotkin TA. Nicotine and the adolescent brain: Insights from an animal model. Neurotoxicol Teratol. 2002; 24(3):369-84. [PubMed: 12009492]

59. Slotkin TA. Fetal nicotine or cocaine exposure: Which one is worse? J Pharmacol Exp Ther. 1998; 285(3):931-45. [PubMed: 9618392]

60. Slotkin TA, McCook EC, Seidler FJ. Cryptic brain cell injury caused by fetal nicotine exposure is associated with persistent elevations of c-fos protooncogene expression. Brain Res. 1997; 750(1-2):180-8. [PubMed: 9098543]

61. Ferrea S, Winterer G. Neuroprotective and neurotoxic effects of nicotine. Pharmacopsychiatry. 2009; 42(6):255-65. [PubMed: 19924585]

62. Kawamata J, Shimohama S. Stimulating nicotinic receptors trigger multiple pathways attenuating cytotoxicity in models of alzheimer's and parkinson's diseases. J Alzheimers Dis. 2011; 24(Suppl 2):95-109. [PubMed: 21403387]

63. Berger F, Gage FH, Vijayaraghavan S. Nicotinic receptor-induced apoptotic cell death of hippocampal progenitor cells. J Neurosci. 1998; 18(17):6871-81. [PubMed: 9712657]

64. Slotkin TA. Cholinergic systems in brain development and disruption by neurotoxicants: Nicotine, environmental tobacco smoke, organophosphates. Toxicol Appl Pharmacol. 2004; 198(2):132-51. [PubMed: 15236950]

65. Levin, ED., TA, S. Developmental neurotoxicity of nicotine. In: Slikker, Lw, Chang, W., editors. Handbook of Developmental Neurotoxicology. San Diego: Academic Press; 1998. p. 587-615.

66. Slotkin, TA. Prenatal exposure to nicotine: What can we learn from animal models?. In: Zagon, IS., Slotkin, TA., editors. Maternal Substance Abuse and the Developing Nervous System. San Diego: Academic Press; 1992. p. 97-124. 
67. Liang K, Poytress BS, Chen Y, Leslie FM, Weinberger NM, Metherate R. Neonatal nicotine exposure impairs nicotinic enhancement of central auditory processing and auditory learning in adult rats. Eur J Neurosci. 2006; 24(3):857-66. [PubMed: 16848798]

68. Britton AF, Vann RE, Robinson SE. Perinatal nicotine exposure eliminates peak in nicotinic acetylcholine receptor response in adolescent rats. J Pharmacol Exp Ther. 2007; 320(2):871-6. [PubMed: 17105825]

69. Abreu-Villaca Y, Seidler FJ, Tate CA, Cousins MM, Slotkin TA. Prenatal nicotine exposure alters the response to nicotine administration in adolescence: Effects on cholinergic systems during exposure and withdrawal. Neuropsychopharmacology. 2004; 29(5):879-90. [PubMed: 14970833]

70. Seidler FJ, Levin ED, Lappi SE, Slotkin TA. Fetal nicotine exposure ablates the ability of postnatal nicotine challenge to release norepinephrine from rat brain regions. Brain Res Dev Brain Res. 1992; 69(2):288-91. [PubMed: 1424104]

71. Aramakis VB, Hsieh CY, Leslie FM, Metherate R. A critical period for nicotine-induced disruption of synaptic development in rat auditory cortex. J Neurosci. 2000; 20(16):6106-16. [PubMed: 10934260]

72. Heath CJ, King SL, Gotti C, Marks MJ, Picciotto MR. Cortico-thalamic connectivity is vulnerable to nicotine exposure during early postnatal development through [alpha]4/[beta]2/[alpha]5 nicotinic acetylcholine receptors. Neuropsychopharmacology 11//print. 2010; 35(12):2324-2338.

73. Liu Z, Neff RA, Berg DK. Sequential interplay of nicotinic and gabaergic signaling guides neuronal development. Science. 2006; 314(5805):1610-3. [PubMed: 17158331]

74. Leslie FM, Gallardo KA, Park MK. Nicotinic acetylcholine receptor-mediated release of [3h]norepinephrine from developing and adult rat hippocampus: Direct and indirect mechanisms. Neuropharmacology. 2002; 42(5):653-61. [PubMed: 11985823]

75. Opanashuk LA, Pauly JR, Hauser KF. Effect of nicotine on cerebellar granule neuron development. Eur J Neurosci. 2001; 13(1):48-56. [PubMed: 11135003]

76. O'Leary KT, Leslie FM. Developmental regulation of nicotinic acetylcholine receptor-mediated [3h]norepinephrine release from rat cerebellum. J Neurochemistry. 2003; 84(5):952-9.

77. Huang LZ, Abbott LC, Winzer-Serhan UH. Effects of chronic neonatal nicotine exposure on nicotinic acetylcholine receptor binding, cell death and morphology in hippocampus and cerebellum. Neuroscience. 2007; 146(4):1854-68. [PubMed: 17434679]

78. Chen WJ, Parnell SE, West JR. Neonatal alcohol and nicotine exposure limits brain growth and depletes cerebellar purkinje cells. Alcohol. 1998; 15(1):33-41. [PubMed: 9426835]

79. Slotkin TA, Skavicus S, Card J, Stadler A, Levin ED, Seidler FJ. Developmental neurotoxicity of tobacco smoke directed toward cholinergic and serotonergic systems: More than just nicotine. Toxicol Sci. 2015; 147(1):178-89. [PubMed: 26085346]

80. Bell JM, Whitmore WL, Queen KL, Orband-Miller L, Slotkin TA. Biochemical determinants of growth sparing during neonatal nutritional deprivation or enhancement: Ornithine decarboxylase, polyamines, and macromolecules in brain regions and heart. Pediatr Res. 1987; 22(5):599-604. [PubMed: 2446242]

81. de Grauw TJ, Myers RE, Scott WJ. Fetal growth retardation in rats from different levels of hypoxia. Biol Neonate. 1986; 49(2):85-9. [PubMed: 3697431]

82. Anblagan D, Jones NW, Costigan C, Parker AJ, Allcock K, Aleong R, et al. Maternal smoking during pregnancy and fetal organ growth: A magnetic resonance imaging study. PloS One. 2013; 8(7):e67223. [PubMed: 23843995]

83. Ekblad M, Korkeila J, Parkkola R, Lapinleimu H, Haataja L, Lehtonen L. Maternal smoking during pregnancy and regional brain volumes in preterm infants. J Pediatr. 2010; 156(2):185-90. e1. [PubMed: 19818449]

84. Roza SJ, Verburg BO, Jaddoe VW, Hofman A, Mackenbach JP, Steegers EA, et al. Effects of maternal smoking in pregnancy on prenatal brain development. The Generation R Study. Eur J Neurosci. 2007; 25(3):611-7. [PubMed: 17298594]

85. Rivkin MJ, Davis PE, Lemaster JL, Cabral HJ, Warfield SK, Mulkern RV, et al. Volumetric MRI study of brain in children with intrauterine exposure to cocaine, alcohol, tobacco, and marijuana. Pediatrics. 2008; 121(4):741-50. [PubMed: 18381539] 
86. Paus T, Nawazkhan I, Leonard G, Perron M, Pike GB, Pitiot A, et al. Corpus callosum in adolescent offspring exposed prenatally to maternal cigarette smoking. Neuroimage. $2008 ; 40(2)$ : 435-41. [PubMed: 18221892]

87. Toro R, Leonard G, Lerner JV, Lerner RM, Perron M, Pike GB, et al. Prenatal exposure to maternal cigarette smoking and the adolescent cerebral cortex. Neuropsychopharmacology. 2008; 33(5): 1019-27. [PubMed: 17609681]

88. Lotfipour S, Ferguson E, Leonard G, Perron M, Pike B, Richer L, et al. Orbitofrontal cortex and drug use during adolescence: Role of prenatal exposure to maternal smoking and bdnf genotype. Arch Gen Psychiatry. 2009; 66(11):1244-52. [PubMed: 19884612]

89. Haghighi A, Schwartz DH, Abrahamowicz M, Leonard GT, Perron M, Richer L, et al. Prenatal exposure to maternal cigarette smoking, amygdala volume, and fat intake in adolescence. JAMA Psychiatry. 2013; 70(1):98-105. [PubMed: 22945562]

90. Liu J, Lester BM, Neyzi N, Sheinkopf SJ, Gracia L, Kekatpure M, et al. Regional brain morphometry and impulsivity in adolescents following prenatal exposure to cocaine and tobacco. JAMA Pediatr. 2013; 167(4):348-54. [PubMed: 23400239]

91. El Marroun H, Schmidt MN, Franken IH, Jaddoe VW, Hofman A, van der Lugt A, et al. Prenatal tobacco exposure and brain morphology: A prospective study in young children. Neuropsychopharmacology. 2014; 39(4):792-800. [PubMed: 24096296]

92. Nijhuis JG, Prechtl HF, Martin CB Jr, Bots RS. Are there behavioural states in the human fetus? Early Hum Dev. 1982; 6(2):177-95. [PubMed: 7094856]

93. Groome LJ, Singh KP, Burgard SL, Neely CL, Deason MA. Motor responsivity during habituation testing of normal human fetuses. J Perinat Med. 1995; 23(3):159-66. [PubMed: 8568607]

94. DiPietro JA, Kivlighan KT, Costigan KA, Rubin SE, Shiffler DE, Henderson JL, et al. Prenatal antecedents of newborn neurological maturation. Child Dev. 2010; 81(1):115-30. [PubMed: 20331657]

95. Dipietro JA. Psychological and psychophysiological considerations regarding the maternal-fetal relationship. Infant Child Dev. 2010; 19(1):27-38. [PubMed: 20228872]

96. Oncken C, Kranzler H, O’Malley P, Gendreau P, Campbell WA. The effect of cigarette smoking on fetal heart rate characteristics. Obstet and Gynecol. 2002; 99(5 Pt 1):751-5.

97. Cowperthwaite B, Hains SM, Kisilevsky BS. Fetal behavior in smoking compared to non-smoking pregnant women. Infant Behav Dev. 2007; 30(3):422-30. [PubMed: 17683752]

98. Zeskind PS, Gingras JL. Maternal cigarette-smoking during pregnancy disrupts rhythms in fetal heart rate. J Pediatr Psychol. 2006; 31(1):5-14. [PubMed: 15905420]

99. Reissland N, Francis B, Kumarendran K, Mason J. Ultrasound observations of subtle movements: A pilot study comparing foetuses of smoking and nonsmoking mothers. Acta Paediatr. 2015; 104(6):596-603. [PubMed: 25761436]

100. DiFranza JR, Lew RA. Effect of maternal cigarette smoking on pregnancy complications and sudden infant death syndrome. J Fam Pract. 1995; 40(4):385-94. [PubMed: 7699353]

101. Dietz PM, England LJ, Shapiro-Mendoza CK, Tong VT, Farr SL, Callaghan WM. Infant morbidity and mortality attributable to prenatal smoking in the U.S. Am J Prev Med. 2010; 39(1): 45-52. [PubMed: 20547278]

102. Lagercrantz H, Slotkin TA. The "stress" of being born. Sci Am. 1986 Apr; 254(4):100-7. [PubMed: 3961465]

103. Ascuitto RJ, Ross-Ascuitto NT. Substrate metabolism in the developing heart. Semin Perinatol. 1996; 20(6):542-63. [PubMed: 9090780]

104. Briggs MM, Seidler FJ, Slotkin TA, Schachat FH. Ontogenetic transition of cardiac myosin heavy chain isoforms in rat ventricle: Effects of fetal exposure to beta-adrenergic agonists or antagonists. J Dev Physiol. 1992; 17(4):201-6. [PubMed: 1357026]

105. Slotkin TA, Lappi SE, McCook EC, Lorber BA, Seidler FJ. Loss of neonatal hypoxia tolerance after prenatal nicotine exposure: Implications for sudden infant death syndrome. Brain Res Bull. 1995; 38(1):69-75. [PubMed: 7552377]

106. Oncken CA, Henry KM, Campbell WA, Kuhn CM, Slotkin TA, Kranzler HR. Effect of maternal smoking on fetal catecholamine concentrations at birth. Pediatr Res. 2003; 53(1):119-24. [PubMed: 12508090] 
107. Slotkin TA, Epps TA, Stenger ML, Sawyer KJ, Seidler FJ. Cholinergic receptors in heart and brainstem of rats exposed to nicotine during development: Implications for hypoxia tolerance and perinatal mortality. Brain Res Dev Brain Res. 1999; 113(1-2):1-12. [PubMed: 10064868]

108. Horne RS, Parslow PM, Harding R. Postnatal development of ventilatory and arousal responses to hypoxia in human infants. Respir Physiol Neurobiol. 2005; 149(1-3):257-71. [PubMed: 15876558]

109. Richardson HL, Walker AM, Horne RS. Maternal smoking impairs arousal patterns in sleeping infants. Sleep. 2009; 32(4):515-21. [PubMed: 19413145]

110. McNamara F, Sullivan CE. Obstructive sleep apnea in infants: Relation to family history of sudden infant death syndrome, apparent life-threatening events, and obstructive sleep apnea. J Pediatr. 2000; 136(3):318-23. [PubMed: 10700687]

111. Schneider J, Mitchell I, Singhal N, Kirk V, Hasan SU. Prenatal cigarette smoke exposure attenuates recovery from hypoxemic challenge in preterm infants. Am J Respir Crit Care Med. 2008; 178(5):520-6. [PubMed: 18565950]

112. Kahn A, Groswasser J, Sottiaux M, Kelmanson I, Rebuffat E, Franco P, et al. Prenatal exposure to cigarettes in infants with obstructive sleep apneas. Pediatrics. 1994; 93(5):778-83. [PubMed: 8165078]

113. Franco P, Groswasser J, Hassid S, Lanquart JP, Scaillet S, Kahn A. Prenatal exposure to cigarette smoking is associated with a decrease in arousal in infants. J Pediatr. 1999; 135(1):34-8. [PubMed: 10393601]

114. Horne RS, Franco P, Adamson TM, Groswasser J, Kahn A. Influences of maternal cigarette smoking on infant arousability. Early Hum Dev. 2004; 79(1):49-58. [PubMed: 15282122]

115. Sawnani H, Jackson T, Murphy T, Beckerman R, Simakajornboon N. The effect of maternal smoking on respiratory and arousal patterns in preterm infants during sleep. Am J Respir Crit Care Med. 2004; 169(6):733-8. [PubMed: 14684558]

116. Stephan-Blanchard E, Chardon K, Leke A, Delanaud S, Djeddi D, Libert JP, et al. In utero exposure to smoking and peripheral chemoreceptor function in preterm neonates. Pediatrics. 2010; 125(3):e592-9. [PubMed: 20176675]

117. Gunnerbeck A, Wikstrom AK, Bonamy AK, Wickstrom R, Cnattingius S. Relationship of maternal snuff use and cigarette smoking with neonatal apnea. Pediatrics. 2011 Sep; 128(3):5039. [PubMed: 21873701]

118. Chang AB, Wilson SJ, Masters IB, Yuill M, Williams J, Williams G, et al. Altered arousal response in infants exposed to cigarette smoke. Arch Dis Child. 2003; 88(1):30-3. [PubMed: 12495956]

119. Hafstrom O, Milerad J, Sundell HW. Prenatal nicotine exposure blunts the cardiorespiratory response to hypoxia in lambs. Am J Respir Crit Care Med. 2002; 166(12 Pt 1):1544-9. [PubMed: 12471072]

120. Campos M, Bravo E, Eugenin J. Respiratory dysfunctions induced by prenatal nicotine exposure. Clin Exp Pharmacol Physiol. 2009; 36(12):1205-17. [PubMed: 19473189]

121. Kinney HC. Brainstem mechanisms underlying the sudden infant death syndrome: Evidence from human pathologic studies. Dev Psychobiol. 2009; 51(3):223-33. [PubMed: 19235901]

122. Stroud LR, Paster RL, Goodwin MS, Shenassa E, Buka S, Niaura R, et al. Maternal smoking during pregnancy and neonatal behavior: A large-scale community study. Pediatrics. 2009; 123(5):e842-8. [PubMed: 19403478]

123. Law KL, Stroud LR, LaGasse LL, Niaura R, Liu J, Lester BM. Smoking during pregnancy and newborn neurobehavior. Pediatrics. 2003; 111(6 Pt 1):1318-23. [PubMed: 12777547]

124. Hurt RD, Renner CC, Patten CA, Ebbert JO, Offord KP, Schroeder DR, et al. Iqmik--a form of smokeless tobacco used by pregnant alaska natives: Nicotine exposure in their neonates. J Matern Fetal Neonatal Med. 2005; 17(4):281-9. [PubMed: 16147838]

125. Mansi G, Raimondi F, Pichini S, Capasso L, Sarno M, Zuccaro P, et al. Neonatal urinary cotinine correlates with behavioral alterations in newborns prenatally exposed to tobacco smoke. Pediatr Res. 2007; 61(2):257-61. [PubMed: 17237732] 
126. Godding V, Bonnier C, Fiasse L, Michel M, Longueville E, Lebecque P, et al. Does in utero exposure to heavy maternal smoking induce nicotine withdrawal symptoms in neonates? Pediatr Res. 2004; 55(4):645-51. [PubMed: 14739371]

127. Stroud LR, Paster RL, Papandonatos GD, Niaura R, Salisbury AL, Battle C, et al. Maternal smoking during pregnancy and newborn neurobehavior: Effects at 10 to 27 days. J Pediatr. 2009; 154(1):10-6. [PubMed: 18990408]

128. Yolton K, Khoury J, Xu Y, Succop P, Lanphear B, Bernert JT, et al. Low-level prenatal exposure to nicotine and infant neurobehavior. Neurotoxicol Teratol. 2009; 31(6):356-63. [PubMed: 19619640]

129. Espy KA, Fang H, Johnson C, Stopp C, Wiebe SA. Prenatal tobacco exposure: Developmental outcomes in the neonatal period. Dev Psychol. 2011; 47(1):153-6. [PubMed: 21038943]

130. McDonald SD, Walker M, Perkins SL, Beyene J, Murphy K, Gibb W, et al. The effect of tobacco exposure on the fetal hypothalamic-pituitary-adrenal axis. BJOG. 2006; 113(11):1289-95. [PubMed: 17014678]

131. Varvarigou AA, Petsali M, Vassilakos P, Beratis NG. Increased cortisol concentrations in the cord blood of newborns whose mothers smoked during pregnancy. J Perinat Med. 2006; 34(6):466-70. [PubMed: 17140296]

132. Varvarigou AA, Liatsis SG, Vassilakos P, Decavalas G, Beratis NG. Effect of maternal smoking on cord blood estriol, placental lactogen, chorionic gonadotropin, FSH, LH, and cortisol. J Perinat Med. 2009; 37(4):364-9. [PubMed: 19290844]

133. Ramsay DS, Bendersky MI, Lewis M. Effect of prenatal alcohol and cigarette exposure on twoand six-month-old infants' adrenocortical reactivity to stress. J Pediatr Psychol. 1996; 21(6):83340. [PubMed: 8990727]

134. Schuetze P, Lopez FA, Granger DA, Eiden RD. The association between prenatal exposure to cigarettes and cortisol reactivity and regulation in 7-month-old infants. Dev Psychobiol. 2008; 50(8):819-34. [PubMed: 18690653]

135. Stroud LR, Papandonatos GD, Rodriguez D, McCallum M, Salisbury AL, Phipps MG, et al. Maternal smoking during pregnancy and infant stress response: Test of a prenatal programming hypothesis. Psychoneuroendocrinology. 2014; 48:29-40. [PubMed: 24999830]

136. Maccari S, Darnaudery M, Morley-Fletcher S, Zuena AR, Cinque C, Van Reeth O. Prenatal stress and long-term consequences: Implications of glucocorticoid hormones. Neurosci Biobehav Rev. 2003; 27(1-2):119-27. [PubMed: 12732228]

137. Poland RE, Lutchmansingh P, Au D, Edelstein M, Lydecker S, Hsieh C, et al. Exposure to threshold doses of nicotine in utero: I. Neuroendocrine response to restraint stress in adult male offspring Life Sci. 1994; 55(20):1567-75. [PubMed: 7968228]

138. Poland RE, Lutchmansingh P, Au D, Hsieh C, Acosta S, Lydecker S, et al. Exposure to threshold doses of nicotine in utero: II. Neuroendocrine response to nicotine in adult male offspring Brain Res Dev Brain Res. 1994; 83(2):278-84. [PubMed: 7697884]

139. Poland RE, Lutchmansingh P, Au D, McGeoy S, Que M, Acosta S, et al. Exposure to threshold doses of nicotine in utero: Iii Augmentation of the prolactin and acth response to 8-oh dpat by desipramine treatment is compromised in adult male offspring. Neurotoxicology. 1996; 17(2): 351-8. [PubMed: 8856731]

140. Kable JA, Coles CD, Lynch ME, Carroll J. The impact of maternal smoking on fast auditory brainstem responses. Neurotoxicology and teratology. 2009; 31(4):216-24. [PubMed: 19224709]

141. Katbamna B, Klutz N, Pudrith C, Lavery JP, Ide CF. Prenatal smoke exposure: Effects on infant auditory system and placental gene expression. Neurotoxicol Teratol. 2013; 38:61-71. [PubMed: 23665419]

142. Korres S, Riga M, Balatsouras D, Papadakis C, Kanellos P, Ferekidis E. Influence of smoking on developing cochlea. Does smoking during pregnancy affect the amplitudes of transient evoked otoacoustic emissions in newborns? Int J Pediatr Otorhinolaryngol. 2007; 71(5):781-6. [PubMed: 17343925]

143. Peck JD, Neas B, Robledo C, Saffer E, Beebe L, Wild RA. Intrauterine tobacco exposure may alter auditory brainstem responses in newborns. Acta Obstet Gynecol Scand. 2010; 89(4):592-6. [PubMed: 20367434] 
144. Key AP, Ferguson M, Molfese DL, Peach K, Lehman C, Molfese VJ. Smoking during pregnancy affects speech-processing ability in newborn infants. Environ Health Perspect. 2007; 115(4):6239. [PubMed: 17450234]

145. Weitzman M, Govil N, Liu YH, Lalwani AK. Maternal prenatal smoking and hearing loss among adolescents. JAMA Otolaryngol Head Neck Surg. 2013; 139(7):669-77. [PubMed: 23788030]

146. Lacy RT, Mactutus CF, Harrod SB. Prenatal iv nicotine exposure produces a sex difference in sensorimotor gating of the auditory startle reflex in adult rats. Int J Dev Neurosci. 2011; 29(2): 153-61. [PubMed: 21145386]

147. Rodier PM. Structural--functional relationships in experimentally induced brain damage. Prog Brain Res. 1988; 73:335-48. [PubMed: 3047802]

148. Ernst M, Moolchan ET, Robinson ML. Behavioral and neural consequences of prenatal exposure to nicotine. J Am Acad Child Adolesc Psychiatry. 2001; 40(6):630-41. [PubMed: 11392340]

149. Wakschlag LS, Pickett KE, Cook E Jr, Benowitz NL, Leventhal BL. Maternal smoking during pregnancy and severe antisocial behavior in offspring: A review. Am J Public Health. 2002; 92(6):966-74. [PubMed: 12036791]

150. D’Onofrio BM, Van Hulle CA, Waldman ID, Rodgers JL, Harden KP, Rathouz PJ, et al. Smoking during pregnancy and offspring externalizing problems: An exploration of genetic and environmental confounds. Dev Psychopathol. 2008; 20(1):139-64. [PubMed: 18211732]

151. Gaysina D, Fergusson DM, Leve LD, Horwood J, Reiss D, Shaw DS, et al. Maternal smoking during pregnancy and offspring conduct problems: Evidence from 3 independent genetically sensitive research designs. JAMA Psychiatry. 2013; 70(9):956-63. [PubMed: 23884431]

152. Wiebe SA, Clark CA, De Jong DM, Chevalier N, Espy KA, Wakschlag L. Prenatal tobacco exposure and self-regulation in early childhood: Implications for developmental psychopathology. Dev Psychopathol. 2015; 27(2):397-409. [PubMed: 25997761]

153. Estabrook R, Massey SH, Clark CA, Burns JL, Mustanski BS, Cook EH, et al. Separating familylevel and direct exposure effects of smoking during pregnancy on offspring externalizing symptoms: Bridging the behavior genetic and behavior teratologic divide. Behav Genet. 2015

154. Ashford J, van Lier PA, Timmermans M, Cuijpers P, Koot HM. Prenatal smoking and internalizing and externalizing problems in children studied from childhood to late adolescence. $\mathrm{J}$ Am Acad Child Adolesc Psychiatry. 2008; 47(7):779-87. [PubMed: 18520960]

155. Brion MJ, Victora C, Matijasevich A, Horta B, Anselmi L, Steer C, et al. Maternal smoking and child psychological problems: Disentangling causal and noncausal effects. Pediatrics. 2010; 126(1):e57-65. [PubMed: 20587678]

156. Williams GM, O'Callaghan M, Najman JM, Bor W, Andersen MJ, Richards D, et al. Maternal cigarette smoking and child psychiatric morbidity: A longitudinal study. Pediatrics. 1998; 102(1):e11. [PubMed: 9651463]

157. Roza SJ, Verhulst FC, Jaddoe VW, Steegers EA, Mackenbach JP, Hofman A, et al. Maternal smoking during pregnancy and child behaviour problems: The Generation R Study. Int J Epidemiol. 2009; 38(3):680-9. [PubMed: 18775874]

158. Robinson M, McLean NJ, Oddy WH, Mattes E, Bulsara M, Li J, et al. Smoking cessation in pregnancy and the risk of child behavioural problems: A longitudinal prospective cohort study. $\mathrm{J}$ Epidemiol Community Health. 2010; 64(7):622-9. [PubMed: 19703906]

159. Moylan S, Gustavson K, Overland S, Karevold EB, Jacka FN, Pasco JA, et al. The impact of maternal smoking during pregnancy on depressive and anxiety behaviors in children: The norwegian mother and child cohort study. BMC Med. 2015; 13:24. [PubMed: 25644294]

160. Carter S, Paterson J, Gao W, Iusitini L. Maternal smoking during pregnancy and behaviour problems in a birth cohort of 2-year-old pacific children in New Zealand. Early Hum Dev. 2008; 84(1):59-66. [PubMed: 17499944]

161. Yolton K, Cornelius M, Ornoy A, McGough J, Makris S, Schantz S. Exposure to neurotoxicants and the development of attention deficit hyperactivity disorder and its related behaviors in childhood. Neurotoxicol Teratol. 2014; 44:30-45. [PubMed: 24846602]

162. Thapar A, Rice F, Hay D, Boivin J, Langley K, van den Bree M, et al. Prenatal smoking might not cause attention-deficit/hyperactivity disorder: Evidence from a novel design. Biol Psychiatry. 2009; 66(8):722-7. [PubMed: 19596120] 
163. Milberger S, Biederman J, Faraone SV, Jones J. Further evidence of an association between maternal smoking during pregnancy and attention deficit hyperactivity disorder: Findings from a high-risk sample of siblings. J Clin Child Psychol. 1998; 27(3):352-8. [PubMed: 9789194]

164. Fried PA, O'Connell CM, Watkinson B. 60- and 72-month follow-up of children prenatally exposed to marijuana, cigarettes, and alcohol: Cognitive and language assessment. J Dev Behav Pediatr. 1992; 13(6):383-91. [PubMed: 1469105]

165. Fried PA, Watkinson B, Gray R. A follow-up study of attentional behavior in 6-year-old children exposed prenatally to marihuana, cigarettes, and alcohol. Neurotoxicol Teratol. 1992; 14(5):299_ 311. [PubMed: 1454038]

166. Cornelius MD, Ryan CM, Day NL, Goldschmidt L, Willford JA. Prenatal tobacco effects on neuropsychological outcomes among preadolescents. J Dev Behav Pediatr. 2001; 22(4):217-25. [PubMed: 11530894]

167. Makin J, Fried PA, Watkinson B. A comparison of active and passive smoking during pregnancy: Long-term effects. Neurotoxicol Teratol. 1991; 13(1):5-12. [PubMed: 2046627]

168. Lambe M, Hultman C, Torrang A, Maccabe J, Cnattingius S. Maternal smoking during pregnancy and school performance at age 15. Epidemiology. 2006 Sep; 17(5):524-30. [PubMed: 16878043]

169. Sexton M, Fox NL, Hebel JR. Prenatal exposure to tobacco: II. Effects on cognitive functioning at age three. Int J Epidemiol. 1990; 19(1):72-7. [PubMed: 2351527]

170. Batstra L, Hadders-Algra M, Neeleman J. Effect of antenatal exposure to maternal smoking on behavioural problems and academic achievement in childhood: Prospective evidence from a dutch birth cohort. Early Hum Dev. 2003; 75(1-2):21-33. [PubMed: 14652157]

171. Eskenazi B, Trupin LS. Passive and active maternal smoking during pregnancy, as measured by serum cotinine, and postnatal smoke exposure II. Effects on neurodevelopment at age 5 years. Am J Epidemiol. 1995; 142(9 Suppl):S19-29. [PubMed: 7572983]

172. Clifford A, Lang L, Chen R. Effects of maternal cigarette smoking during pregnancy on cognitive parameters of children and young adults: A literature review. Neurotoxicol Teratol. 2012; 34(6): 560-70. [PubMed: 23022448]

173. Yang S, Decker A, Kramer MS. Exposure to parental smoking and child growth and development: A cohort study. BMC Pediatr. 2013; 13:104. [PubMed: 23842036]

174. Knopik VS. Maternal smoking during pregnancy and child outcomes: Real or spurious effect? Dev Neuropsychol. 2009; 34(1):1-36. [PubMed: 19142764]

175. Mortensen EL, Michaelsen KF, Sanders SA, Reinisch JM. A dose-response relationship between maternal smoking during late pregnancy and adult intelligence in male offspring. Paediatr Perinat Epidemiol. 2005; 19(1):4-11. [PubMed: 15670102]

176. Treur JL, Willemsen G, Bartels M, Geels LM, van Beek JH, Huppertz C, et al. Smoking during adolescence as a risk factor for attention problems. Biol psychiatry. 2015; 78(9):656-63. [PubMed: 25092631]

177. Sobrian SK, Ali SF, Slikker W Jr, Holson RR. Interactive effects of prenatal cocaine and nicotine exposure on maternal toxicity, postnatal development and behavior in the rat. Mol Neurobiol. 1995; 11(1-3):121-43. [PubMed: 8561957]

178. Gaworski CL, Carmines EL, Faqi AS, Rajendran N. In utero and lactation exposure of rats to $1 \mathrm{r} 4 \mathrm{f}$ reference cigarette mainstream smoke: Effect on prenatal and postnatal development. Toxicol Sci. 2004; 79(1):157-69. [PubMed: 14976347]

179. Schneider T, Ilott N, Brolese G, Bizarro L, Asherson PJ, Stolerman IP. Prenatal exposure to nicotine impairs performance of the 5-choice serial reaction time task in adult rats. Neuropsychopharmacology. 2011; 36(5):1114-25. [PubMed: 21289608]

180. Sobrian SK, Holson RR. Effects of pre- and neonatal nicotine exposure in rodents: Inconsistent evidence. Ilar J. 2011; 52(3):251-94. [PubMed: 23382143]

181. Vaglenova J, Birru S, Pandiella NM, Breese CR. An assessment of the long-term developmental and behavioral teratogenicity of prenatal nicotine exposure. Behav Brain Res. 2004; 150(1-2): 159-70. [PubMed: 15033289]

182. Portugal GS, Wilkinson DS, Turner JR, Blendy JA, Gould TJ. Developmental effects of acute, chronic, and withdrawal from chronic nicotine on fear conditioning. Neurobiol Learn Mem. 2012; 97(4):482-94. [PubMed: 22521799] 
183. Cutler AR, Wilkerson AE, Gingras JL, Levin ED. Prenatal cocaine and/or nicotine exposure in rats: Preliminary findings on long-term cognitive outcome and genital development at birth. Neurotoxicol Teratol. 1996; 18(6):635-43. [PubMed: 8947940]

184. Levin ED, Briggs SJ, Christopher NC, Rose JE. Prenatal nicotine exposure and cognitive performance in rats. Neurotoxicol Teratol. 1993; 15(4):251-60. [PubMed: 8413079]

185. Levin ED, Wilkerson A, Jones JP, Christopher NC, Briggs SJ. Prenatal nicotine effects on memory in rats: Pharmacological and behavioral challenges. Brain Res Dev Brain Res. 1996; 97(2):207-15. [PubMed: 8997505]

186. Sorenson CA, Raskin LA, Suh Y. The effects of prenatal nicotine on radial-arm maze performance in rats. Pharmacol Biochem Behav. 1991; 40(4):991-3. [PubMed: 1816586]

187. Nakauchi S, Malvaez M, Su H, Kleeman E, Dang R, Wood MA, et al. Early postnatal nicotine exposure causes hippocampus-dependent memory impairments in adolescent mice: Association with altered nicotinic cholinergic modulation of ltp, but not impaired LTP. Neurobiol Learn Mem. 2015; 118:178-88. [PubMed: 25545599]

188. Ankarberg E, Fredriksson A, Eriksson P. Neurobehavioural defects in adult mice neonatally exposed to nicotine: Changes in nicotine-induced behaviour and maze learning performance. Behav Brain Res. 2001 Sep; 14123(2):185-92.

189. Eppolito AK, Smith RF. Long-term behavioral and developmental consequences of pre- and perinatal nicotine. Pharmacol Biochem Behav. 2006; 85(4):835-41. [PubMed: 17196635]

190. Yanai J, Pick CG, Rogel-Fuchs Y, Zahalka EA. Alterations in hippocampal cholinergic receptors and hippocampal behaviors after early exposure to nicotine. Brain Res Bull. 1992; 29(3-4):3638. [PubMed: 1393609]

191. Paz R, Barsness B, Martenson T, Tanner D, Allan AM. Behavioral teratogenicity induced by nonforced maternal nicotine consumption. Neuropsychopharmacology. 2007; 32(3):693-9. [PubMed: 16554741]

192. Franke RM, Park M, Belluzzi JD, Leslie FM. Prenatal nicotine exposure changes natural and drug-induced reinforcement in adolescent male rats. Eur J Neurosci. 2008 Jun; 27(11):2952-61. [PubMed: 18588535]

193. Eppolito AK, Bachus SE, McDonald CG, Meador-Woodruff JH, Smith RF. Late emerging effects of prenatal and early postnatal nicotine exposure on the cholinergic system and anxiety-like behavior. Neurotoxicology and teratology. 2010 May-Jun;32(3):336-45. [PubMed: 20060465]

194. Sobrian SK, Marr L, Ressman K. Prenatal cocaine and/or nicotine exposure produces depression and anxiety in aging rats. Prog Neuropsychopharmacol Biol Psychiatry. 2003; 27(3):501-18. [PubMed: 12691787]

195. Hayatbakhsh MR, Sadasivam S, Mamun AA, Najman JM, Williams GM, O’Callaghan MJ. Maternal smoking during and after pregnancy and lung function in early adulthood: A prospective study. Thorax. 2009; 64(9):810-4. [PubMed: 19525264]

196. Moshammer H, Hoek G, Luttmann-Gibson H, Neuberger MA, Antova T, Gehring U, et al. Parental smoking and lung function in children: An international study. Am J Respir Crit Care Med. 2006; 173(11):1255-63. [PubMed: 16484675]

197. Cunningham J, Dockery DW, Speizer FE. Maternal smoking during pregnancy as a predictor of lung function in children. Am J Epidemiol. 1994; 139(12):1139-52. [PubMed: 8209873]

198. Hoo AF, Henschen M, Dezateux C, Costeloe K, Stocks J. Respiratory function among preterm infants whose mothers smoked during pregnancy. Am J Respir Crit Care Med. 1998; 158(3):7005. [PubMed: 9730993]

199. Stocks J, Hislop A, Sonnappa S. Early lung development: Lifelong effect on respiratory health and disease. Lancet Respir Med. 2013; 1(9):728-42. [PubMed: 24429276]

200. McEvoy CT, Schilling D, Clay N, Jackson K, Go MD, Spitale P, et al. Vitamin c supplementation for pregnant smoking women and pulmonary function in their newborn infants: A randomized clinical trial. JAMA. 2014; 311(20):2074-82. [PubMed: 24838476]

201. Stoddard JJ, Gray B. Maternal smoking and medical expenditures for childhood respiratory illness. Am J Public Health. 1997; 87(2):205-9. [PubMed: 9103098] 
202. Neuman A, Hohmann C, Orsini N, Pershagen G, Eller E, Kjaer HF, et al. Maternal smoking in pregnancy and asthma in preschool children: A pooled analysis of eight birth cohorts. Am J Respir Crit Care Med. 2012; 186(10):1037-43. [PubMed: 22952297]

203. Burke H, Leonardi-Bee J, Hashim A, Pine-Abata H, Chen Y, Cook DG, et al. Prenatal and passive smoke exposure and incidence of asthma and wheeze: Systematic review and meta-analysis. Pediatrics. 2012; 129(4):735-44. [PubMed: 22430451]

204. Spindel ER, McEvoy CT. The role of nicotine in the effects of maternal smoking during pregnancy on lung development and childhood respiratory disease. Implications for dangers of ecigarettes. Am J Respir Crit Care Med. 193(5):486-94.

205. Wongtrakool C, Wang N, Hyde DM, Roman J, Spindel ER. Prenatal nicotine exposure alters lung function and airway geometry through alpha7 nicotinic receptors. Am J Respir Cell Mol Biol. 2012 May; 46(5):695-702. [PubMed: 22246862]

206. Proskocil BJ, Sekhon HS, Clark JA, Lupo SL, Jia Y, Hull WM, et al. Vitamin c prevents the effects of prenatal nicotine on pulmonary function in newborn monkeys. Am J Respir Crit Care Med. 2005; 171(9):1032-9. [PubMed: 15709053]

207. Sekhon HS, Keller JA, Benowitz NL, Spindel ER. Prenatal nicotine exposure alters pulmonary function in newborn rhesus monkeys. American journal of respiratory and critical care medicine. 2001; 164(6):989-94. [PubMed: 11587984]

208. Sekhon HS, Jia Y, Raab R, Kuryatov A, Pankow JF, Whitsett JA, et al. Prenatal nicotine increases pulmonary alpha7 nicotinic receptor expression and alters fetal lung development in monkeys. $\mathrm{J}$ Clin Invest. 1999; 103(5):637-47. [PubMed: 10074480]

209. Sekhon HS, Keller JA, Proskocil BJ, Martin EL, Spindel ER. Maternal nicotine exposure upregulates collagen gene expression in fetal monkey lung. Association with alpha7 nicotinic acetylcholine receptors. Am J Respir Cell Mol Biol. 2002; 26(1):31-41. [PubMed: 11751201]

210. Sekhon HS, Proskocil BJ, Clark JA, Spindel ER. Prenatal nicotine exposure increases connective tissue expression in foetal monkey pulmonary vessels. Eur Respir J. 2004; 23(6):906-15. [PubMed: 15219006]

211. Elliot J, Vullermin P, Robinson P. Maternal cigarette smoking is associated with increased inner airway wall thickness in children who die from sudden infant death syndrome. Am J Respir Crit Care Med. 1998; 158(3):802-6. [PubMed: 9731008]

212. Lavezzi AM, Corna MF, Alfonsi G, Matturri L. Possible role of the alpha7 nicotinic receptors in mediating nicotine's effect on developing lung - implications in unexplained human perinatal death. BMC Pulm Med. 2014; 14:11. [PubMed: 24484641]

213. Joubert BR, Felix JF, Yousefi P, Bakulski KM, Just AC, Breton C, et al. DNA methylation in newborns and maternal smoking in pregnancy: Genome-wide consortium meta-analysis. American J Hum Genet. 2016; 98(4):680-96.

214. Chhabra D, Sharma S, Kho AT, Gaedigk R, Vyhlidal CA, Leeder JS, et al. Fetal lung and placental methylation is associated with in utero nicotine exposure. Epigenetics. 2014; 9(11): 1473-84. [PubMed: 25482056]

215. Breton CV, Siegmund KD, Joubert BR, Wang X, Qui W, Carey V, et al. Prenatal tobacco smoke exposure is associated with childhood DNA cpg methylation. PloS One. 2014; 9(6):e99716. [PubMed: 24964093]

216. Liu J, Naeem E, Tian J, Lombardi V, Kwong K, Akbari O, et al. Sex-specific perinatal nicotineinduced asthma in rat offspring. Am J Respir Cell Mol Biol. 2013 Jan; 48(1):53-62. [PubMed: 23002101]

217. Rehan VK, Liu J, Sakurai R, Torday JS. Perinatal nicotine-induced transgenerational asthma. Am J Physiol Lung Cell Mol Physiol. 2013; 305(7):L501-7. [PubMed: 23911437]

218. Rehan VK, Liu J, Naeem E, Tian J, Sakurai R, Kwong K, et al. Perinatal nicotine exposure induces asthma in second generation offspring. BMC Med. 2012; 10:129. [PubMed: 23106849]

219. Haley KJ, Lasky-Su J, Manoli SE, Smith LA, Shahsafaei A, Weiss ST, et al. Runx transcription factors: Association with pediatric asthma and modulated by maternal smoking. Am J Physiol Lung Cell Mol Physiol. 2011; 301(5):L693-701. [PubMed: 21803869]

220. Suter MA, Abramovici AR, Griffin E, Branch DW, Lane RH, Mastrobattista J, et al. In utero nicotine exposure epigenetically alters fetal chromatin structure and differentially regulates 
transcription of the glucocorticoid receptor in a rat model. Birth Defects Res A Clin Mol Teratol. 2015; 103(7):583-8. [PubMed: 26172404]

221. Kann L, Kinchen S, Shanklin SL, Flint KH, Kawkins J, Harris WA, et al. Youth risk behavior surveillance--united states, 2013. MMWR Surveill Summ. 2014; 63(Suppl 4):1-168.

222. Substance Abuse and Mental Health Services Administration. Results from the 2013 National Survey on Drug Use and Health: Summary of National Findings. Rockville, MD: Substance Abuse and Mental Health Services Administration; 2014.

223. U.S. Department of Health and Human Services. Preventing Tobacco Use Among Youth and Young Adults: A Report of the Surgeon General. Atlanta, GA: U.S Department of Health and Human Services, Centers for Disease Control and Prevention, National Center for Chronic Disease Prevention and Health Promotion; 2012.

224. Mermelstein RJ. Adapting to a changing tobacco landscape: Research implications for understanding and reducing youth tobacco use. Am J Prev Med. 2014; 47(2 Suppl 1):S87-9. [PubMed: 25044200]

225. Arrazola RA, Neff LJ, Kennedy SM, Holder-Hayes E, Jones CD. Tobacco use among middle and high school students--united states, 2013. MMWR Morb Mortal Wkly Rep. 2014; 63(45):10216. [PubMed: 25393220]

226. Bunnell RE, Agaku IT, Arrazola RA, Apelberg BJ, Caraballo RS, Corey CG, et al. Intentions to smoke cigarettes among never-smoking us middle and high school electronic cigarette users: National youth tobacco survey, 2011-2013. Nicotine Tob Res. 2015; 17(2):228-35. [PubMed: 25143298]

227. Arrazola RA, Singh T, Corey CG, Husten CG, Neff LJ, Apelberg BJ, et al. Tobacco use among middle and high school students - United States, 2011-2014. MMWR Morb Mortal Wkly Rep. 2015; 64(14):381-5. [PubMed: 25879896]

228. Johnston, LD., O’Malley, PM., Miech, RA., Bachman, JG., Schulenberg, JE. Monitoring the future national survey results on drug use: 1975-2014: Overview, key findings on adolescent drug use. Ann Arbor, MI: Institute for Social Research, The University of Michigan;

229. Wills TA, Knight R, Sargent JD, Gibbons FX, Pagano I, Williams RJ. Longitudinal study of ecigarette use and onset of cigarette smoking among high school students in Hawaii. Tob Control. 2016

230. Barrington-Trimis JL, Urman R, Berhane K, Unger JB, Cruz TB, Pentz MA, et al. E-cigarettes and future cigarette use. Pediatrics. 2016

231. Schramm NL, Egli RE, Winder DG. Ltp in the mouse nucleus accumbens is developmentally regulated. Synapse. 2002; 45(4):213-9. [PubMed: 12125042]

232. Sowell ER, Peterson BS, Thompson PM, Welcome SE, Henkenius AL, Toga AW. Mapping cortical change across the human life span. Nat Neurosci. 2003; 6(3):309-15. [PubMed: 12548289]

233. Giedd JN, Blumenthal J, Jeffries NO, Castellanos FX, Liu H, Zijdenbos A, et al. Brain development during childhood and adolescence: A longitudinal mri study. Nat Neurosci. 1999; 2(10):861-3. [PubMed: 10491603]

234. Burgaleta M, Johnson W, Waber DP, Colom R, Karama S. Cognitive ability changes and dynamics of cortical thickness development in healthy children and adolescents. NeuroImage. 2014; 84:810-9. [PubMed: 24071525]

235. Russo SJ, Dietz DM, Dumitriu D, Morrison JH, Malenka RC, Nestler EJ. The addicted synapse: Mechanisms of synaptic and structural plasticity in nucleus accumbens. Trends Neurosci. 2010; 33(6):267-76. [PubMed: 20207024]

236. Dierker L, Swendsen J, Rose J, He J, Merikangas K. Transitions to regular smoking and nicotine dependence in the adolescent national comorbidity survey (ncs-a). Ann Behav Med. 2012 Jun; 43(3):394-401. [PubMed: 22160800]

237. Hu MC, Griesler PC, Schaffran C, Wall MM, Kandel DB. Trajectories of criteria of nicotine dependence from adolescence to early adulthood. Drug Alcohol Depend. 2012; 125(3):283-9. [PubMed: 22513378]

238. Volkow N. Altered pathways: Drug abuse and age of onset. Addict Prof. 2006:26-29. 
239. O’Loughlin J, DiFranza J, Tyndale RF, Meshefedjian G, McMillan-Davey E, Clarke PB, et al. Nicotine-dependence symptoms are associated with smoking frequency in adolescents. Am J Prev Med. 2003 Oct; 25(3):219-25. [PubMed: 14507528]

240. DiFranza JR, Rigotti NA, McNeill AD, Ockene JK, Savageau JA, St Cyr D, et al. Initial symptoms of nicotine dependence in adolescents. Tob Control. 2000 Sep; 9(3):313-9. [PubMed: 10982576]

241. Kandel DB, Chen K. Extent of smoking and nicotine dependence in the united states: 1991-1993. Nicotine Tob Res. 2000; 2(3):263-74. [PubMed: 11082827]

242. Brenhouse HC, Sonntag KC, Andersen SL. Transient d1 dopamine receptor expression on prefrontal cortex projection neurons: Relationship to enhanced motivational salience of drug cues in adolescence. J Neurosci. 2008; 28(10):2375-82. [PubMed: 18322084]

243. Belluzzi JD, Lee AG, Oliff HS, Leslie FM. Age-dependent effects of nicotine on locomotor activity and conditioned place preference in rats. Psychopharmacology. 2004; 174(3):389-95. [PubMed: 14740150]

244. Adriani W, Spijker S, Deroche-Gamonet V, Laviola G, Le Moal M, Smit AB, et al. Evidence for enhanced neurobehavioral vulnerability to nicotine during periadolescence in rats. The $\mathrm{J}$ Neurosci. 2003 Jun; 123(11):4712-6.

245. Klein LC. Effects of adolescent nicotine exposure on opioid consumption and neuroendocrine responses in adult male and female rats. Exp Clin Psychopharmacol. 2001; 9(3):251-61. [PubMed: 11534535]

246. Wallace TL, Bertrand D. Importance of the nicotinic acetylcholine receptor system in the prefrontal cortex. Biochem Pharmacol. 2013; 85(12):1713-20. [PubMed: 23628449]

247. McClernon FJ, Hiott FB, Huettel SA, Rose JE. Abstinence-induced changes in self-report craving correlate with event-related fmri responses to smoking cues. Neuropsychopharmacology. 2005; 30(10):1940-7. [PubMed: 15920499]

248. Due DL, Huettel SA, Hall WG, Rubin DC. Activation in mesolimbic and visuospatial neural circuits elicited by smoking cues: Evidence from functional magnetic resonance imaging. Am J Psychiatry. 2002; 159(6):954-60. [PubMed: 12042183]

249. Smolka MN, Buhler M, Klein S, Zimmermann U, Mann K, Heinz A, et al. Severity of nicotine dependence modulates cue-induced brain activity in regions involved in motor preparation and imagery. Psychopharmacology. 2006; 184(3-4):577-88. [PubMed: 16133128]

250. McBride D, Barrett SP, Kelly JT, Aw A, Dagher A. Effects of expectancy and abstinence on the neural response to smoking cues in cigarette smokers: An fMRI study. Neuropsychopharmacology. 2006; 31(12):2728-38. [PubMed: 16598192]

251. Sharma A, Brody AL. In vivo brain imaging of human exposure to nicotine and tobacco. Handb Exp Pharmacol. 2009(192):145-71.

252. Brody AL, Mandelkern MA, London ED, Olmstead RE, Farahi J, Scheibal D, et al. Cigarette smoking saturates brain alpha 4 beta 2 nicotinic acetylcholine receptors. Arch Gen Psychiatry. 2006; 63(8):907-15. [PubMed: 16894067]

253. Franklin TR, Wang Z, Wang J, Sciortino N, Harper D, Li Y, et al. Limbic activation to cigarette smoking cues independent of nicotine withdrawal: A perfusion fMRI study. Neuropsychopharmacology. 2007; 32(11):2301-9. [PubMed: 17375140]

254. McClernon FJ, Kozink RV, Rose JE. Individual differences in nicotine dependence, withdrawal symptoms, and sex predict transient fmri-bold responses to smoking cues. Neuropsychopharmacology. 2008; 33(9):2148-57. [PubMed: 17987060]

255. Dagher A, Bleicher C, Aston JA, Gunn RN, Clarke PB, Cumming P. Reduced dopamine d1 receptor binding in the ventral striatum of cigarette smokers. Synapse. 2001; 42(1):48-53. [PubMed: 11668590]

256. Rubinstein ML, Luks TL, Dryden WY, Rait MA, Simpson GV. Adolescent smokers show decreased brain responses to pleasurable food images compared with nonsmokers. Nicotine Tob Res. 2011 Aug; 13(8):751-5. [PubMed: 21454914]

257. Rubinstein ML, Luks TL, Moscicki AB, Dryden W, Rait MA, Simpson GV. Smoking-related cueinduced brain activation in adolescent light smokers. J Adolesc Health. 2011 Jan; 48(1):7-12. [PubMed: 21185518] 
258. Jacobsen LK, Picciotto MR, Heath CJ, Frost SJ, Tsou KA, Dwan RA, et al. Prenatal and adolescent exposure to tobacco smoke modulates the development of white matter microstructure. J Neurosci. 2007; 27(49):13491-8. [PubMed: 18057207]

259. Jacobsen LK, Slotkin TA, Mencl WE, Frost SJ, Pugh KR. Gender-specific effects of prenatal and adolescent exposure to tobacco smoke on auditory and visual attention. Neuropsychopharmacology. 2007; 32(12):2453-64. [PubMed: 17375135]

260. Lee JH, Lim Y, Wiederhold BK, Graham SJ. A functional magnetic resonance imaging (fMRI) study of cue-induced smoking craving in virtual environments. Appl Psychophysiol Biofeedback. 2005; 30(3):195-204. [PubMed: 16167185]

261. Galvan A, Poldrack RA, Baker CM, McGlennen KM, London ED. Neural correlates of response inhibition and cigarette smoking in late adolescence. Neuropsychopharmacology. 2011; 36(5): 970-8. [PubMed: 21270772]

262. Peters J, Bromberg U, Schneider S, Brassen S, Menz M, Banaschewski T, et al. Lower ventral striatal activation during reward anticipation in adolescent smokers. Am J Psychiatry. 2011; 168(5):540-9. [PubMed: 21362742]

263. Hall FS, Der-Avakian A, Gould TJ, Markou A, Shoaib M, Young JW. Negative affective states and cognitive impairments in nicotine dependence. Neurosci Biobehav Rev. 2015; 58:168-85. [PubMed: 26054790]

264. Starr JM, Deary IJ, Fox HC, Whalley LJ. Smoking and cognitive change from age 11 to 66 years: A confirmatory investigation. Addict Behav. 2007; 32(1):63-8. [PubMed: 16650620]

265. Paelecke-Habermann Y, Paelecke M, Giegerich K, Reschke K, Kubler A. Implicit and explicit reward learning in chronic nicotine use. Drug Alcohol Depend. 2013; 129(1-2):8-17. [PubMed: 23098679]

266. Williams JW, Plassman BL, Burke J, Benjamin S. Preventing alzheimer's disease and cognitive decline. Evid Rep Technol Assess. 2010; (193):1-727.

267. Heffernan T, O’Neill T, Moss M. Smoking and everyday prospective memory: A comparison of self-report and objective methodologies. Drug Alcohol Depend. 2010; 112(3):234-8. [PubMed: 20800391]

268. Heffernan TM, O'Neill TS, Moss M. Smoking-related prospective memory deficits in a realworld task. Drug Alcohol Depend. 2012; 120(1-3):1-6. [PubMed: 21726964]

269. Jacobsen LK, Krystal JH, Mencl WE, Westerveld M, Frost SJ, Pugh KR. Effects of smoking and smoking abstinence on cognition in adolescent tobacco smokers. Biol Psychiatry. 2005; 57(1): 56-66. [PubMed: 15607301]

270. Jacobsen LK, Mencl WE, Constable RT, Westerveld M, Pugh KR. Impact of smoking abstinence on working memory neurocircuitry in adolescent daily tobacco smokers. Psychopharmacology. 2007; 193(4):557-66. [PubMed: 17505817]

271. Fried PA, Watkinson B, Gray R. Neurocognitive consequences of cigarette smoking in young adults--a comparison with pre-drug performance. Neurotoxicol Teratol. 2006; 28(4):517-25. [PubMed: 16904287]

272. Chamberlain SR, Odlaug BL, Schreiber LR, Grant JE. Association between tobacco smoking and cognitive functioning in young adults. Am J Addict. 2012; 21(Suppl 1):S14-9. [PubMed: 23786505]

273. Musso F, Bettermann F, Vucurevic G, Stoeter P, Konrad A, Winterer G. Smoking impacts on prefrontal attentional network function in young adult brains. Psychopharmacology. 2007; 191(1):159-69. [PubMed: 16937098]

274. Chen R, Clifford A, Lang L, Anstey KJ. Is exposure to secondhand smoke associated with cognitive parameters of children and adolescents?--a systematic literature review. Ann Epidemiol. 2013; 23(10):652-61. [PubMed: 23969303]

275. Yolton K, Dietrich K, Auinger P, Lanphear BP, Hornung R. Exposure to environmental tobacco smoke and cognitive abilities among u.S. 1-3Children and adolescents. Environ Health Perspect. 2005; 113(1):98-103. [PubMed: 15626655]

276. Glassman AH, Helzer JE, Covey LS, Cottler LB, Stetner F, Tipp JE, et al. Smoking, smoking cessation, and major depression. JAMA. 1990; 264(12):1546-9. [PubMed: 2395194] 
277. Jackson JG, Diaz FJ, Lopez L, de Leon J. A combined analysis of worldwide studies demonstrates an association between bipolar disorder and tobacco smoking behaviors in adults. Bipolar Disord. 2015; 17(6):575-97. [PubMed: 26238269]

278. Bakhshaie J, Zvolensky MJ, Goodwin RD. Cigarette smoking and the onset and persistence of depression among adults in the united states: 1994-2005. Compr Psychiatry. 2015; 60:142-8. [PubMed: 25882595]

279. de Leon J, Dadvand M, Canuso C, White AO, Stanilla JK, Simpson GM. Schizophrenia and smoking: An epidemiological survey in a state hospital. Am J Psychiatry. 1995; 152(3):453-5. [PubMed: 7864277]

280. Lasser K, Boyd JW, Woolhandler S, Himmelstein DU, McCormick D, Bor DH. Smoking and mental illness: A population-based prevalence study. JAMA. 2000; 284(20):2606-10. [PubMed: 11086367]

281. McClernon FJ, Kozink RV, Lutz AM, Rose JE. 24-h smoking abstinence potentiates fMRI-bold activation to smoking cues in cerebral cortex and dorsal striatum. Psychopharmacology. 2009 May; 204(1):25-35. [PubMed: 19107465]

282. Vanable PA, Carey MP, Carey KB, Maisto SA. Smoking among psychiatric outpatients: Relationship to substance use, diagnosis, and illness severity. Psychol Addict Behav. 2003; 17(4): 259-65. [PubMed: 14640821]

283. Vogel JS, Hurford DP, Smith JV, Cole A. The relationship between depression and smoking in adolescents. Adolescence. 2003; 38(149):57-74. [PubMed: 12803454]

284. Glasheen C, Hedden SL, Forman-Hoffman VL, Colpe LJ. Cigarette smoking behaviors among adults with serious mental illness in a nationally representative sample. Ann Epidemiol. 2014; 24(10):776-80. [PubMed: 25169683]

285. Ziedonis D, Hitsman B, Beckham JC, Zvolensky M, Adler LE, Audrain-McGovern J, et al. Tobacco use and cessation in psychiatric disorders: National institute of mental health report. Nicotine Tob Res. 2008; 10(12):1691-715. [PubMed: 19023823]

286. Kutlu MG, Parikh V, Gould TJ. Nicotine addiction and psychiatric disorders. Int Rev Neurobiol. 2015; 124:171-208. [PubMed: 26472530]

287. Goriounova NA, Mansvelder HD. Nicotine exposure during adolescence leads to short- and longterm changes in spike timing-dependent plasticity in rat prefrontal cortex. J Neurosci. 2012; 32(31):10484-93. [PubMed: 22855798]

288. Spaeth AM, Barnet RC, Hunt PS, Burk JA. Adolescent nicotine exposure disrupts context conditioning in adulthood in rats. Pharmacol Biochem Behav. 2010; 96(4):501-6. [PubMed: 20655941]

289. Goriounova NA, Mansvelder HD. Short- and long-term consequences of nicotine exposure during adolescence for prefrontal cortex neuronal network function. Cold Spring Harb Perspect Med. 2012; 2(12):a012120. [PubMed: 22983224]

290. Poorthuis RB, Goriounova NA, Couey JJ, Mansvelder HD. Nicotinic actions on neuronal networks for cognition: General principles and long-term consequences. Biochem Pharmacol. 2009 Oct 1; 78(7):668-76. [PubMed: 19426718]

291. Holliday ED, Nucero P, Kutlu MG, Oliver C, Connelly KL, Gould TJ, et al. Long-term effects of chronic nicotine on emotional and cognitive behaviors and hippocampus cell morphology in mice: Comparisons of adult and adolescent nicotine exposure. Eur J Neuroscience. 2016

292. Counotte DS, Goriounova NA, Li KW, Loos M, van der Schors RC, Schetters D, et al. Lasting synaptic changes underlie attention deficits caused by nicotine exposure during adolescence. Nat Neurosci. 2011; 14(4):417-9. [PubMed: 21336271]

293. Slawecki CJ, Gilder A, Roth J, Ehlers CL. Increased anxiety-like behavior in adult rats exposed to nicotine as adolescents. Pharmacol Biochem Behav. 2003; 75(2):355-61. [PubMed: 12873627]

294. Iniguez SD, Warren BL, Parise EM, Alcantara LF, Schuh B, Maffeo ML, et al. Nicotine exposure during adolescence induces a depression-like state in adulthood. Neuropsychopharmacology. 2009; 34(6):1609-24. [PubMed: 19092782]

295. Ribeiro-Carvalho A, Lima CS, Nunes-Freitas AL, Filgueiras CC, Manhaes AC, Abreu-Villaca Y. Exposure to nicotine and ethanol in adolescent mice: Effects on depressive-like behavior during exposure and withdrawal. Behav Brain Res. 2011; 221(1):282-9. [PubMed: 21402108] 
296. Smith LN, McDonald CG, Bergstrom HC, Brielmaier JM, Eppolito AK, Wheeler TL, et al. Longterm changes in fear conditioning and anxiety-like behavior following nicotine exposure in adult versus adolescent rats. Pharmacol Biochem Behav. 2006; 85(1):91-7. [PubMed: 16919320]

297. Slawecki CJ, Thorsell AK, El Khoury A, Mathe AA, Ehlers CL. Increased crf-like and npy-like immunoreactivity in adult rats exposed to nicotine during adolescence: Relation to anxiety-like and depressive-like behavior. Neuropeptides. 2005; 39(4):369-77. [PubMed: 16038974]

298. Viveros MP, Marco EM, File SE. Nicotine and cannabinoids: Parallels, contrasts and interactions. Neurosci Biobehav Rev. 2006; 30(8):1161-81. [PubMed: 17049986]

299. Kandel, D. Stages and pathways of drug involvement: Examining the gateway hypothesis. Cambridge, England: Cambridge University Press; 2002.

300. Kandel, DBYK. Stages of Drug Involvement in the US Population. In: Kandel, DB., editor. Stages and Pathways of Drug Involvement: Examining the Gateway Hypothesis. Cambridge, England: Cambridge University Press; 2002.

301. Kandel DB, Kandel ER. A molecular basis for nicotine as a gateway drug. The New England journal of medicine. 2014 Nov 20; 371(21):2038-9.

302. Dao JM, McQuown SC, Loughlin SE, Belluzzi JD, Leslie FM. Nicotine alters limbic function in adolescent rat by a 5-ht1 a receptor mechanism. Neuropsychopharmacology. 2011; 36(7):131931. [PubMed: 21412223]

303. Mojica CY, Belluzzi JD, Leslie FM. Age-dependent alterations in reward-seeking behavior after brief nicotine exposure. Psychopharmacology. 2014; 231(8):1763-73. [PubMed: 24030468]

304. Kandel ER, Kandel DB. Shattuck lecture. A molecular basis for nicotine as a gateway drugs. N Engl J Med. 2014; 371(10):932-43. [PubMed: 25184865]

305. Levine A, Huang Y, Drisaldi B, Griffin EA Jr, Pollak DD, Xu S, et al. Molecular mechanism for a gateway drug: Epigenetic changes initiated by nicotine prime gene expression by cocaine. Sci Transl Med. 2011; 3(107):107ra109.

306. Slotkin TA, Lappi SE, Seidler FJ. Impact of fetal nicotine exposure on development of rat brain regions: Critical sensitive periods or effects of withdrawal? Brain Res Bull. 1993; 31(3-4):31928. [PubMed: 8490731]

307. Slotkin TA, Seidler FJ, Spindel ER. Prenatal nicotine exposure in rhesus monkeys compromises development of brainstem and cardiac monoamine pathways involved in perinatal adaptation and sudden infant death syndrome: Amelioration by vitamin c. Neurotoxicol Teratol. 2011; 33(3): 431-4. [PubMed: 21320590]

308. Golub MS, Slotkin TA, Tarantal AF, Pinkerton KE. Visual recognition memory and auditory brainstem response in infant rhesus monkeys exposed perinatally to environmental tobacco smoke. Brain Res. 2007; 1151:102-6. [PubMed: 17399690]

309. Slotkin TA, Pinkerton KE, Tate CA, Seidler FJ. Alterations of serotonin synaptic proteins in brain regions of neonatal rhesus monkeys exposed to perinatal environmental tobacco smoke. Brain Res. 2006; 1111(1):30-5. [PubMed: 16876770]

310. Slotkin TA, Seidler FJ, Qiao D, Aldridge JE, Tate CA, Cousins MM, et al. Effects of prenatal nicotine exposure on primate brain development and attempted amelioration with supplemental choline or vitamin c: Neurotransmitter receptors, cell signaling and cell development biomarkers in fetal brain regions of rhesus monkeys. Neuropsychopharmacology. 2005 Jan; 30(1):129-44. [PubMed: 15316571]

311. Farsalinos KE, Spyrou A, Tsimopoulou K, Stefopoulos C, Romagna G, Voudris V. Nicotine absorption from electronic cigarette use: Comparison between first and new-generation devices. Sci Rep. 2014; 4:4133. [PubMed: 24569565]

312. Bullen C, McRobbie H, Thornley S, Glover M, Lin R, Laugesen M. Effect of an electronic nicotine delivery device (e cigarette) on desire to smoke and withdrawal, user preferences and nicotine delivery: Randomised cross-over trial. Tob Control. 2010; 19(2):98-103. [PubMed: 20378585]

313. Ramoa CP, Hiler MM, Spindle TR, Lopez AA, Karaoghlanian N, Lipato T, et al. Electronic cigarette nicotine delivery can exceed that of combustible cigarettes: A preliminary report. Tob Control. 2016; 25(e1):e6-9. [PubMed: 26324250] 
314. Wagener TL, Floyd EL, Stepanov I, Driskill LM, Frank SG, Meier E, et al. Have combustible cigarettes met their match? The nicotine delivery profiles and harmful constituent exposures of second-generation and third-generation electronic cigarette users. Tob Control. 2016

315. Lange P, Celli B, Agusti A, Boje Jensen G, Divo M, Faner R, et al. Lung-function trajectories leading to chronic obstructive pulmonary disease. N Engl J Med. 2015; 373(2):111-22. [PubMed: 26154786]

316. Martinez FD. The origins of asthma and chronic obstructive pulmonary disease in early life. Proc Am Thorac Soc. 2009; 6(3):272-7. [PubMed: 19387029]

317. Stern DA, Morgan WJ, Wright AL, Guerra S, Martinez FD. Poor airway function in early infancy and lung function by age 22 years: A non-selective longitudinal cohort study. Lancet. 2007; 370(9589):758-64. [PubMed: 17765525]

318. National Institutes of Health. [November 16, 2016] Adolescent brain cognitive development study. http://addictionresearch.nih.gov/abcd-study

319. Claudio L, Kwa WC, Russell AL, Wallinga D. Testing methods for developmental neurotoxicity of environmental chemicals. Toxicol Appl Pharmacol. 2000; 164(1):1-14. [PubMed: 10739739]

320. Chlorpyrifos - end-use products cancellation order 1/02. Agency Environmental Protection, editor: OPP-34203J; FRL-6819-6. 2002

321. Slotkin TA, Card J, Stadler A, Levin ED, Seidler FJ. Effects of tobacco smoke on pc12 cell neurodifferentiation are distinct from those of nicotine or benzo[a]pyrene. Neurotoxicol Teratol. 2014; 43:19-24. [PubMed: 24642111]

322. Hall BJ, Cauley M, Burke DA, Kiany A, Slotkin TA, Levin ED. Cognitive and behavioral impairments evoked by low-level exposure to tobacco smoke components: Comparison with nicotine alone. Toxicol Sci. 2016; 151(2):236-44. [PubMed: 26919958]

323. [25 Aug 2016] H.R. 1375 - 114th Congress: Child Nicotine Poisoning Prevention Act of 2015. Aug 25, 2016. https://www.govtrack.us/congress/bills/114/hr1375

324. Food and Drug Administration, HHS. Deeming Tobacco Products To Be Subject to the Federal Food, Drug, and Cosmetic Act, as Amended by the Family Smoking Prevention and Tobacco Control Act; Restrictions on the Sale and Distribution of Tobacco Products and Required Warning Statements for Tobacco Products. Final rule Fed Regist. 2016 May 10; 81(90):289739106. [PubMed: 27192730]

325. Giedd JN. Structural magnetic resonance imaging of the adolescent brain. Annals of the New York Academy of Sciences. 2004 Jun.1021:77-85. [PubMed: 15251877]

326. Centers for Disease Control and Prevention. Best Practices for Comprehensive Tobacco Control Programs - 2014. Atlanta, Georgia: U.S Department of Health and Human Services, Centers for Disease Control and Prevention, National Center for Chronic Disease Prevention and Health Promotion, Office on Smoking and Health; 2014. 


\section{Highlights}

- Electronic cigarettes are often promoted as a safer alternative to combusted cigarettes.

- Human and animal research supports that nicotine contributes to the adverse effects of gestational tobacco exposure on fetal development.

- $\quad$ Nicotine exposure during adolescence is associated with cognitive deficits.

- Measures to protect pregnant women and adolescents from nicotine exposure are warranted. 